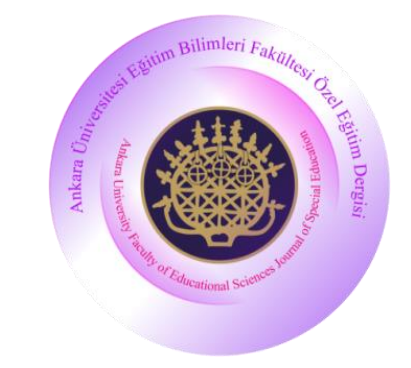

ARAŞTIRMA

\section{Ankara Üniversitesi Eğitim Bilimleri Fakültesi Özel Eğitim Dergisi}

\author{
Yıl: 2020, Cilt: 21, Sayı: 1, Sayfa No: 95-122
}

doi: 10.21565/ozelegitimdergisi.616520

\title{
Güzel Sanatlar Eğitimi Bölümü Öğretmen Adaylarının Özel Gereksinimli Öğrencilere Yönelik Metaforik Algıları (Gazi Üniversitesi Örneği)*
}

\author{
Eylem Dayı $* *$ \\ Gazi Üniversitesi
}

\author{
Gökhan Açıkgöz ${ }^{* * *}$ \\ Gazi Üniversitesi
}

Öz

$\mathrm{Bu}$ araştırma, Gazi Eğitim Fakültesi Güzel Sanatlar Eğitimi Bölümü öğretmen adaylarının özel gereksinimli öğrencilere yönelik geliştirdikleri metaforları belirlemeyi amaçlamıştır. Araştırmada nitel araştırma modeli kapsamında olgubilim deseni kullanılmıştır. Araştırmanın çalıșma grubunu Güzel Sanatlar Eğitimi Bölümü 1, 2, 3 ve 4. sınıfa devam eden gönüllü 267 öğretmen adayı oluşturmuştur. Araştırmanın verileri "Engelli öğrenciler benim için ...... gibidir; çünkü, ...... dır." cümlesinin yer aldığı açık uçlu form ile toplanmıştır. Verilerin analizinde içerik analizi tekniği kullanılmıştır. Araştırmada elde edilen bulgulara göre öğretmen adaylarının sekiz kategoride 102 metafor ürettiği görülmüştür. Araştırma sonucunda öğretmen adaylarının özel gereksinimli öğrenciler için en çok çiçek ve herkes metaforlarını kullandıkları ortaya çıkmıştır. Öğretmen adaylarının özel gereksinimli öğrencilere yönelik algılarının genelde olumlu olduğu sonucuna varılmıştır.

Anahtar sözcükler: Özel gereksinimli öğrenciler, metafor, metoforik algı, öğretmen adayları, güzel sanatlar eğitimi.

\section{$\underline{\text { Önerilen Atı Sekli }}$}

Dayı, E., Açıkgöz, G., \& Elçi, A. N. (2020). Güzel Sanatlar Eğitimi Bölümü öğretmen adaylarının özel gereksinimli öğrencilere yönelik metaforik algıları (Gazi Üniveritesi örneği). Ankara Üniversitesi Eğitim Bilimleri Fakültesi Özel Eğitim Dergisi, 21(1), 95-122. doi: 10.21565/ozelegitimdergisi.616520

\footnotetext{
*28. Ulusal Özel Eğitim Kongresi'nde sözlü bildiri olarak sunulmuştur, 11-13 Ekim 2018, Eskişehir.

${ }^{* *}$ Sorumlu Yazar: Dr. Öğr. Üyesi, E-posta: eylemd@ gazi.edu.tr, https://orcid.org/0000-0003-1020-5846

***Arş. Gör., E-posta: gokhan264@gmail.com, https://orcid.org/0000-0002-8548-4360

****Arş. Gör., E-posta: aysenurkucukelci@gmail.com, https://orcid.org/0000-0002-8153-4105
} 
Bütün çocuklar fiziksel ve öğrenme özellikleri bakımından birbirlerinden farklılıklar göstermektedir. Çocukların çoğu genel eğitim programından yararlanır. Özel gereksinimli çocukların ise fiziksel ve/veya öğrenme özellikleri, eğitimden tam olarak yararlanabilmeleri için bireyselleştirilmiş bir özel eğitim programı ve ilgili hizmetler gerektirecek şekilde normdan aşağı veya yukarı farklılık gösterir. Özel gereksinimli çocuklar terimi, öğrenmede zorluk yaşayan çocukların yanı sıra, müfredat ve öğretimde değişiklik yapmayı ve potansiyellerini gerçekleştirmelerine yardımcı olunması gereken performansları çok yüksek düzeyde çocukları da içermektedir. $\mathrm{Bu}$ durum özel gereksinimli çocukların, okuldan tam anlamıla faydalanmaları noktasında bireysel olarak geliştirilmiş bir eğitim programının olmasını gerekli kılmaktadır (Heward, Alber-Morgan \& Konrad, 2017).

Türkiye'de özel gereksinimli çocukların eğitimi Milli Eğitim Bakanlığı (MEB) Özel Eğitim ve Rehberlik Hizmetleri Genel Müdürlüğüne bağlı resmi kurumlar ve Özel Öğretim Kurumları Genel Müdürlüğüne bağlı özel kurumlarca yürütülmektedir. Bu kurumlarda özel eğitim ve branş öğretmenleri görev yapmaktadır. Milli Eğitim Bakanlığı Özel Eğitim ve Rehberlik Hizmetleri Genel Müdürlüğüne bağlı resmi kurumlarda özel gereksinimli çocuklar bireyselleştirilmiş̧ eğitim programları (BEP) çerçevesinde gelişim alanları ve akademik becerilerini geliştirmeye yönelik dersler almaktadırlar. Özel gereksinimli bireyler için müzik ve görsel sanatlar gibi alan derslerinin özel eğitim okul ve sınıflarının haftalık ders çizelgelerinde yer alması, özel gereksinimli bireyin sosyal bir varlık olma temelinde, yaratıcılığını geliştirme, kendini ifade edebilme, içinde bulunduğu ortamı tanıma, bir değer olduğunun farkına vararak kişiliğini geliştirmesine ve kendini gerçekleştirmesine katkıda bulunmaktadır (Ertemin, 1997; Şendurur \& Barış, 2002; Taşmektepligil, Yılmaz, İmamoğlu \& Kılcıgil, 2006). Özellikle orta veya ağır düzeyde zihinsel engelliler/otizm spektrum bozukluğu olan çocukların devam ettiği özel eğitim okullarında "görsel sanatlar ve el becerileri" ile "müzik ve oyun" derslerinin üçer ders saati olduğunu ve bunların aynı çizelgede yer alan "matematik", "günlük yaşam becerileri" ve "sosyal beceriler" gibi temel dersler sayllabilecek derslerle aynı ders saatine sahip olduğu dikkati çekmektedir (Milli Eğitim Bakanlı̆̆ı [MEB], 2019a; MEB, 2019b). Ayrıca özel gereksinimli bireylerin eğitim hizmetlerini düzenleyen Özel Eğitim Hizmetleri Yönetmeliği (2018) incelendiğinde özel eğitim okul ve sınıflarında "dersler özel eğitim öğretmenleri tarafından okutulur" ibaresinin yanında "ilkokullarda din kültürü ve ahlak bilgisi; ortaokul ve lise düzeyinde ise din kültürü ve ahlak bilgisi, görsel sanatlar, müzik ve beden eğitimi alanlarına ilişkin dersler ile meslek dersleri, ilgili alan öğretmenleri tarafindan okutulur" açıklaması yer almaktadır. Yönetmelikte yer alan bu tür açıklamalardan özel gereksinimli bireylerin eğitiminden sadece özel eğitim öğretmenlerinin sorumlu olmadığı sonucu çıkarılmaktadır. Dolayısıyla alan öğretmenlerinin de özel eğitime gereksinimi olan bireyler hakkında belli düzeyde öğretimi nasıl uyarlayacakları, davranışları nasıl yöneteceklerine yönelik bilgi ve beceri sahibi olmaları önemli olmaktadır. Bununla ilgili olarak eğitim fakültelerinin lisans programları incelendiğinde ise Güzel Sanatlar Eğitimi Bölümü resim ve müzik öğretmenliği programının dördüncü yılında "özel eğitim ve kaynaştırma" adlı haftada iki ders saati olan bir ders olduğu görülmektedir (Yükseköğretim Kurulu [YÖK], 2019a; YÖK, 2019b). Ancak Çitil, Kararkoç ve Küçüköziğit (2018) yılında eğitim fakültelerinde farklı branşlara okutulan iki kredilik "özel eğitim” lisans dersinin öğretmen adaylarının bilgi düzeylerine ve engellilere yönelik tutumlarına etkisini belirlemeyi amaçladıkları araştırmanın bulgularına göre öğretmen adaylarının özel eğitim ve engelliler hakkında bilgi düzeyleri artmış olmasına karşın engelli bireylere yönelik tutumlarında anlamlı bir değişikliğin meydana gelmediği görülmüştür.

Özel gereksinimli çocukların normal gelişim gösteren çocuklarla benzer özellikleri olsa da fiziksel ve öğrenme özellikleri bakımından belli düzeylerdeki farklılıkları onları aynı yaştaki normal gelişim gösteren akranlarından önemli şekillerde ayırmaktadır. Bir çocuğun herhangi bir uzvunun olmaması ya da uzuvların işlevini istenilen düzeyde yerine getirememesi, işitememesi, görememesi ya da zihinsel, sosyal ve duygusal anlamda yaşadığı zorluklar vb. özel gereksinimli çocukları, normal gelişim gösteren akranlarından ayıran farklılıklar arasında sayılabilir. Bu farklılıkların nasıl algılandığı ve bu farklılıklara yönelik nasıl bir eğitim yapıldığı, çocuğun okuldaki ve okul sonrasındaki başarısı üzerinde önemli bir etkiye sahip olmaktadır (Heward vd., 2017; Özyürek, 2006). Özel gereksinimli çocukların farklı özellikleri dikkate alınarak herhangi bir destek sağlanmaması bu çocukların normal gelişim gösteren akranlarına sunulan eğitim ortamlarından faydalanmalarını zorlaştırmaktadır (Cavkaytar, 2017). Bununla birlikte özel gereksininimli bireylerin farklılıklarına yönelik toplumdaki kişilerin 
olumsuz tutumları ve uygun olmayan davranışları onların okula, işe veya toplumdaki etkinliklere tam olarak katılma konusunda engeller yaşamalarına neden olmaktadır (Çolak \& Çetin, 2014; Heward vd., 2017).

Alan yazında özel gereksinimli bireylerin öğretmen adayları tarafından nasıl algılandıklarına yönelik araştırmalar bulunmaktadır. Tortop, Kandemir, Kaya ve Demir (2015) öğretmen adaylarının zihinsel engelli birey kavramına ilişkin algılarını ortaya çıkarmayı hedefledikleri araştırmada sınıf, okul öncesi, Türkçe, matematik, sosyal bilgiler ve fen bilgisi öğretmenliği bölümlerinin 2, 3 ve 4. sınıfında okuyan 29 öğretmen adayı ile nitel bir çalışma yapmıştır. Araştırma sonucunda katılımcıların “Zihin engelli birey deyince aklınıza ne geliyor?” sorusuna verdikleri yanıtlar analiz edilmiştir. Analiz sonucunda ortaya çıkan 11 farklı temanın ilk beş sırasında; "yaşamak için başkalarına muhtaç olan birey", "zihin gelişimleri geri olan birey", "sosyal yaşantısı engellenmiş birey”, "birtakım becerileri yerine getiremeyen birey", "ilgiye ihtiyacı olan birey" şeklinde temaların yer aldığı belirtilmiştir. Bir cümle ile toparlanmalı sonuç. Bu temaların çıkması yazarları nereye götürmüş? Nasıl bir çıkarımda bulunmuşlar?

Shippen, Crites, Houchins, Ramsey ve Simon (2005) yaptıkları çalışmada öğretmen adaylarının, özel eğitime giriş kursunun tamamlanmasından önce ve sonra genel eğitim ortamlarında özel gereksinimli öğrencilere hizmet etme konusunda, kabul etmeme/kabul etme ve kayg1/sakinlik gibi iki farklı skaladaki algılarını karşılaştırmıştır. Ayrıca her öğretmen adayı ismini kullanmadan Soodak, Podell ve Lehman, 1998'den uyarlanmış olan Hizmet Öncesi Kaynaştırma Anketi (Pre-service Inclusion Survey) doldurmuştur. Anket, özel gereksinimli öğrencilerle kaynaştırma sınıflarında çalışmaya yönelik tek paragraflık bir senaryodan oluşmaktadır. Bu senaryodaki özel gereksinimli öğrencilerin işitme, öğrenme, zihinsel yetersizlikleri, davranış bozuklukları veya tekerlekli sandalye kullanımını gerektiren fiziksel yetersizlikleri olduğu açıklanmıştır. Senaryonun okunmasının ardından öğretmen adayları 17 maddeden oluşan, senaryoya karşı olumsuz, biraz olumsuz, nötr, biraz olumlu ve olumlu duygular olarak tanımlanan 5'li likert tipi bir ölçekte derecelendirilmiş olan anketi doldurmuşlardır. Çalışmanın sonuçları, özel eğitim kursunun öğretmen adaylarının, genel eğitim ortamlarında özel gereksinimli öğrencilere hizmet etme konusundaki kaygı ve bu durumu kabul etmeme düzeylerini önemli ölçüde azalttığını göstermiştir.

Impecoven-Lind (2004) araştırmasında öğretmen adaylarının özel gereksinimli öğrencilere yönelik algılarını araştırmak ve öğretmen eğitimcilerine, öğretmen yetiştirme programlarını değiştirmek üzere, gelecekteki öğretmenleri farklı bir grup öğrenci ile çalışmaya daha iyi hazırlamak için kullanılabilecek bilgiler sağlamayı amaçlamıştır. Sonuçlar öğretmen adaylarının özel gereksinimli öğrencilere yönelik algılarının oldukça olumlu olduğunu göstermiştir. Öğretmen adaylarının tamamladığı erken çocukluk, ilköğretim, ortaöğretim gibi alan deneyimlerine göre gruplar arasında farklılıklar görülmüştür. Birkaç tema, öğretmen adaylarının özel gereksinimli öğrencilere yönelik mevcut algılarını şekillendiren faktörler olarak ortaya çıkmıştır. En yaygın faktörler aile, arkadaşlar, iş, okul, uygulamalı deneyimler ve dini inançlar olarak bulgulanmıştır.

Eğitimin her kademesinde oldukça önemli bir sayıya sahip olan özel gereksinimli öğrencilere yönelik öğretmen adaylarının düşünce ve görüşleri, öğrencilerine yaklaşımlarını ve sunulacak eğitim öğretim hizmetlerini etkileyebilmektedir (Heward vd., 2017). Bu nedenle hem alanda temel dersler kadar ders saati süresine sahip derslerin bulunması ve bu derslere girmekle yükümlü olan hem de lisans eğitiminde özel gereksinimli bireylere yönelik eğitim alan Eğitim fakültelerinin Güzel Sanatlar Eğitimi Bölümü öğretmen adaylarının, özel gereksinimli öğrencilere yönelik algılarını belirlemek önemlidir. Çünkü özel gereksinimli öğrencilerin eğitim ortamında başarılı olması bekleniyorsa, öğretmen adaylarının özel gereksinimli öğrencilere yönelik duygu ve düşüncelerini daha iyi anlamak zorunludur.

Metaforlar, duygu ve düşüncelerin ifade edilmesinde kullanılan bir yöntemdir. Yunancada "metapherein" sözcügü "aktarmak", "taşımak" anlamına gelen metafor bugün iki nesne, olay ya da ilişki arasındaki benzerlikler şeklinde kullanılmaktadır (Draaisma, 2007). Metafor, karmaşık terimleri açıklarken "bir şeyin karşılığını aktarmak" ya da "transfer etmek" olarak tanımlama anlamına gelmektedir (Döş, 2010). Bir başka ifadeyle, bir kelimenin bilinen ve kabul edilen manası yerine söylenmek istenenin farklı yollar, benzetmeler kullanılarak ifade 
edilmesidir (Anılan, 2017). Metaforlar, kullanıldıklarında, tek kelime ile ifade edilen durum, kelime ya da nesnenin daha detaylandırılmış, daha sanatsal bir şekilde dile getirilmesine olanak sağlar. Duygu ve düşüncelerin günlük hayatta dile getirilmesi ve olaylara bakış açısını etkileyen metaforlar, günlük hayatta ve eğitim alanında ifade edilmesi zor olan veya karşı tarafa aktarılması güç olan olguları daha anlaşılır şekilde ifade etmeye yarayabilmektedir. Bu şekilde metaforların insanın iç dünyasından etkilenip, dünyayı yorumlamasına nasıl etki ettiği görülebilir (Arslan \& Bayrakçı, 2006). Metaforik algı ise metafor vasıtasıyla düşünce oluşturma sürecidir (Eraslan, 2011). Sezer (2003) metaforik algı sürecini (a) açıklamak veya anlamlandırmak istediğimiz durum, olay ve kavram gibi soyut bir olgu, (b) soyut olguyu açıklamada kullandığımız somut bir olgu ve olgunun sözlü ifadesi ve (c) soyut ve somut olgu arasında kurulan benzeşmeler olarak aşamalandırmaktadır. Bu süreçte araştırmacı tarafindan ilk olarak derinlemesine analizi yapılacak bir olgu, durum ya da kavram belirlenmektedir. Sonraki aşama, verilen soyut olguyu bir metafor üreterek açıklaması beklenen hedef kitleye sunulmasıdır. En son aşamada ise çalışmaya katılan kişilerin seçtiği metaforun nedenini açıklamada kurdukları benzerlikler ifade edilmektedir.

Eğitimin pek çok alanında metaforlar kullanılabilmektedirler. Örneğin, program geliştirme ve plânlama, eğitim yönetimi ile öğrenmeye isteklendirmek ve yaratıcı düşünceyi geliştirmek amacıyla öğretim alanında kullanımlarına rastlanmaktadır (Arslan \& Bayrakçı, 2006). Alan yazında farklı bölümlerde okuyan öğretmen adaylarının özel gereksinimli öğrencilere yönelik algı ve tutumunun belirlendiği pek çok araştırmaya rastlanmıştır (Aky1ldız, 2017; Impecoven-Lind, 2004; Tortop vd., 2015; Vural, Esentaş \& Işıkgöz, 2018; Yaral1, 2015). Ancak doğrudan hem alanda temel dersler kadar ders saati süresine sahip derslerin bulunması ve bu derslere girmekle yükümlü olan hem de lisans eğitiminde özel gereksinimli bireylere yönelik eğitim alan Eğitim Fakültelerinin Güzel Sanatlar Eğitimi bölümü öğretmen adaylarının özel gereksinimli öğrencilere yönelik algılarını araştıran bir çalışmaya rastlanmamıştır. Bu araştırmada da Gazi Eğitim Fakültesi Güzel Sanatlar Eğitimi Bölümü öğretmen adaylarının engelli öğrencilere yönelik geliştirdikleri metaforların neler olduğunu belilemek amaçlanmıştır. Bu kapsamda aşağıdaki sorulara yanıt aranmıştır:

1. Gazi Eğitim Fakültesi Güzel Sanatlar Eğitimi Bölümü öğretmen adaylarının özel gereksinimli öğrencilere yönelik geliştirdikleri metaforlar nelerdir

2. Belirtilen metaforlar ortak özellik bakımından hangi kavramsal kategoriler ve gerekçeli ifadeler altında toplanmaktadır?

\section{Yöntem}

\section{Araştırma Modeli}

Araştırmada nitel araştırma modeli kapsamında olgubilim deseni kullanılmışıır. Olgubilim deseni, aşina olduğumuz, ancak ayrıntılı bir anlayışa sahip olmadığımız olguları araştırmayı hedefleyen çalışmalar için uygun bir ortam oluşturur (Creswell, 2007; Patton, 2002; Yıldırım \& Şimşek, 2011). Bu araştırmalarda olguların yapısı, araştırmanın odak konusunu yaşayan veya bu olguyu yansıtabilecek kişilerin veya grupların bakış açısından yorumlanmaya çalışılır (Büyüköztürk, Çakmak, Akgün, Karadeniz \& Demirel, 2016; Creswell, 2007; Gedik, 2016).

\section{Çalışma Grubu}

Araştırmanın katılımcıları amaçlı örneklem yöntemine göre seçilmiştir. Amaçlı örneklemin seçiminde temel amaç, çalışılan konuyla ilgili daha fazla bilgi sunacak kişileri seçmektir (Patton, 2002). Bu örnekleme kapsamında araştırma 2017-2018 eğitim öğretim yılının bahar döneminde Gazi Üniversitesi Gazi Eğitim Fakültesi'nin Güzel Sanatlar Eğitimi Bölümünün resim ve müzik öğretmenliği 1, 2, 3 ve 4. sinıfina kayıtlı olan araştırmaya katılmada gönüllülük kriterini karşılayan toplam 284 öğretmen adayı ile gerçekleştirilmiştir. Araştırmaya katılan 17 öğretmen adayının yanıtları formdaki ifadelerin boş bırakılması, tamamlanmaması veya anlam bütünlüğünün olmaması sebebiyle değerlendirmeye alınmamıştır. Araştırmaya katılan 267 öğretmen adayının demografik özellikleri Tablo 1'de verilmiştir. 
Tablo 1

Öğretmen Adaylarına İlişkin Demografik Bilgiler

\begin{tabular}{lcc}
\hline Özellik & $N$ & $\%$ \\
\hline Cinsiyet & & 72.7 \\
\hline Kadın & 194 & 27.3 \\
Erkek & 73 & 17.6 \\
\hline Sinıf düzeyi & & 20.2 \\
\hline 1 & 47 & 42.3 \\
2 & 54 & 19.9 \\
3 & 113 & 100 \\
4
\end{tabular}

Tablo 1'e bakıldığında araştırmaya katılan öğretmen adaylarının \%72.7'sini kadın, \%27.3'ünü ise erkek öğretmen adaylarının oluşturduğu görülmektedir. Öğretmen adaylarının sınıf düzeylerine ilişkin bilgilere bakıldığında araştırmaya katılan Güzel Sanatlar Eğitimi Bölümünde okuyan öğretmen adaylarının \%17.6'sı birinci, \%20.2'si ikinci, \%42.3’ü üçüncü, \%19.9'u ise dördüncü sınıf düzeyinde olduğu görülmektedir.

\section{Verilerin Toplanması}

Araştırmada öğretmen adaylarının özel gereksinimli öğrencilerle ilgili metaforları açık uçlu anket formu kullanılarak elde edilmiştir. Anket formu iki bölümden oluşmaktadır. Birinci bölümde katılımcı öğretmen adaylarının bölüm, sınıf düzeyi durumunu betimleyen sorular; ikinci bölümde ise öğretmen adaylarının engelli öğrencilere ilişkin sahip oldukları metaforları ortaya çıkarmak amacıyla verilen "Engelli öğrenciler benim için; .... gibi’ dir. Çünkü, .... dır.” cümlesi yer almıştır. Bu cümle metaforik algıları belirlemek için kullanılan kalıp sorusu olduğundan, katılımcılara kalıplarda bir değişiklik yapmamaları ve görüşlerini uygun şekilde ifade etmeleri gerektiği açıklanmıştır. Metaforik algıları belirlemek için kullanılan kalıp cümlesindeki "gibi" ifadesi benzetme yapılması, "çünkü” ifadesi de yapılan benzetmenin mantıklı bir gerekçe ile açıklanması içindir. Bu araştırmada da benzer sebeplerle aynı yol takip edilmiştir.

Özel eğitim literatüründe "özel gereksinimli birey, özel eğitime gereksinimi olan birey ya da özel eğitime ihtiyacı olan birey" terimleri kullanılmasına karşın anket sorularının yöneltildiği çalışma grubunda yer alan özellikle özel eğitim konusunda herhangi bir ders almamış 1, 2 ve 3. sınıf öğretmen adayları tarafindan anket sorusunun anlaşılabilirliğini sağlamak amacıyla anket sorusunda toplum içinde yaygın kullanıma sahip "engelli öğrenci" terimi kullanılmıştır. Ancak araştırmanın raporlaştırılmasında ise bulgular bölümünde öğretmen adaylarının metaforlar için yaptıkları açıklamalardan yapılan alıntılamalar dışında "özel gereksinimli birey/öğrenci” terimine yer verilmiştir.

\section{Verilerin Analizi}

Bu araştırmada öğretmen adaylarının yazılı olarak verdikleri metaforların analizi ve değerlendirilmesinde içerik analizi tekniği kullanılmıştır. İçerik analizinin temel amacı elde edilen verilerin öncelikle kavramsallaştırılması, ardından bu kavramlara yönelik mantıklı bir biçimde düzenlenmesi ve bu kavramları açıklayan durumların kategoriler halinde sunulmasıdır (Yıldırım \& Şimşek, 2011). Bu araştırmada metaforların içerik analizi aşamaları, benzer çalışmalardan (Anılan, 2017; Ateş \& Karatepe, 2013; Büyükalan, Filiz \& Türkmenli, 2019; Derman, 2014; Ekici, 2016; Saban, 2004, 2008, 2009) yararlanılarak eleme ve numaralandırma, kodlama, kategorilerin oluşturulması, geçerlik ve güvenirlik ve verilerin yorumlanması şeklinde gerçekleştirilmiştir.

Verilerin elenmesi ve numaralandırılması. $\mathrm{Bu}$ aşamada verilerin analizi için ilk olarak öğretmen adaylarının doldurdukları kâğıtların araştırma amacına uygun olup olmadığı incelenmiştir. 284 öğretmen adayından 17'sinin kâğıtlarının araştırma amacına uygun doldurulmadığı belirlenmiştir. Metaforların 
yazılmaması, “çünkü” kısmının belirtilen metafora uygun olarak yazılmamış olması gibi durumlar araştırma amacına uygun olmama durumuna örnek gösterilebilir. Bu kağıtlar değerlendirme kapsamından çıkarılmıştır. Ardından araştırma amacına uygun doldurulan kağıtlar birden başlanarak 267'ye kadar numaralandırılmıştır.

Verilerin kodlanması. Kodlama aşamasında, değerlendirmeye alınması kesinleşen kağıtlara ait metaforlar birden başlanarak numaralandırılarak kodlanmıştır. Bu işlemin sonucunda 102 adet kod ortaya çıkmıştır. Öğretmen adaylarının geliştirdikleri kodlar ve metafor ifadeleri bir arada tablolaştırılarak listelenmiştir ve frekans değerleri yazılmıştır.

Kategorilerin oluşturulması. Öğretmen adaylarının ifadeleri, numara sırasına göre listelerenerek ortak özellikleri bakımından ele alınmıştır. Ardından özel gereksinimli öğrencilerle ilgili vurgu yaptıkları özellikler ve bakış açılarına göre değerlendirilmiştir. Bu değerlendirme sonucunda metaforları en iyi temsil ettiği düşünülen sekiz kategori oluşturulmuştur.

Geçerlik ve güvenirlik sağlanması. Bu araştırmada geçerliği sağlamak için formların dağıtılmasından önce öğretmen adaylarına çalışma hakkında kısa bir açıklama yapılmış ve çalışmaya katılmayı isteyip istemedikleri sorulmuştur. Ardından çalışmaya katılmak için gönüllü olan öğretmen adaylarına hazırlanan formun dağıtılmasına, formu doldurmaları için yeterli süre verilmesine, formu doldurma sırasında birbirlerinden yardım almamalarına özen gösterilmiştir. Veri analiz süreci ise aşama aşama ve detaylı bir şekilde raporlandırılmıştır.

Araştırmanın güvenirliğini sağlamak için araştırmada ortaya çıkan kavramsal kategori içinde oluşturulan kodların (metaforların) ilgili kavramsal kategorileri, öğretmen adaylarının özel gereksinimli öğrencilere yönelik metaforik algılarını gösterip göstermedğini doğrulamak için üç araştırmacının oluşturduğu kodlar ve bu kodlara yönelik kategorilerin karşılaştırması yapılmıştır (Creswell, 2007; Houser, 2015; Streubert \& Carpenter, 2011). Araştırma verilerini üç araştırmacı ayrı ayrı kodladıktan sonra oluşturulan kod ve kategori listesine son hali verilmiştir. Veri analizinin güvenirliği, "Güvenirlik = görüşbirliği / görüş birliği + görüş ayrıllı̆̆l" formülü kullanılarak hesaplanmıştır (Miles \& Huberman, 1994). Hesaplama sonucunda kodlayıcılar arası ortalama güvenirlik .93 bulunmuştur. Ayrıca katılımcı numarası verilerek (ÖA2 gibi) öğretmen adaylarının görüşleri bulgularda açıklanmıştır. Verilerin değerlendirilmesi için ise kelime bulutu hazırlanmıştır. Kelime bulutu hazırlanmasında https://wordart.com/create programı kullanılmıştır.

Verilerin yorumlanması. Veri analizi aşamasında elde edilen metaforlar Güzel Sanatlar Eğitimi Bölümü öğretmen adaylarının geliştirdikleri metaforlar kategorileştirilerek ve gerekçeli ifadeleri de belirtilmiş, şekil ve tablolar halinde sunularak yorumlanmıştır.

\section{Bulgular}

Bu bölümde bulgular, amaçlarda yer alan sıraya uygun olarak iki başlık altında sunulmuştur.

\section{Birinci Alt Amaca İlişkin Bulgular}

Birinci alt amaca ilişkin bulgular öğretmen adaylarının özel gereksinimli öğrencilere yönelik geliştirdikleri metaforlar ve bu metaforların frekans değerlerine uygun olarak belirlenmesi şeklinde sunulmuştur. İlk olarak belirlenen bütün metaforlar toplu bir şekilde tabloda verilmiştir. Daha sonra kelime bulutu şekliyle ifade edilmiştir. Tablo 2'de öğretmen adaylarının özel gereksinimli öğrencilere yönelik geliştirdikleri metaforlar gösterilmiştir. Tablo 2'de görüldüğü gibi, Güzel Sanatlar Eğitimi Bölümü öğretmen adayları özel gereksinimli öğrencilere ilişkin 102 adet metafor üretmiş ve üretilen metaforlar öğretmen adaylarının kullanım sıklıklarına göre verilmiştir. Bu metaforlardan öğretmen adaylarının en fazla kullanılan çiçek (31), herkes (24), yapboz (9), keşfedilmemiş ülke (9), melek (7), bebek (7), özel (7), güçlü (7), kapalı kutu (7) ve yardıma muhtaç (7) olduğu görülmektedir. Öğretmen adaylarının kullandıkları sonraki metaforların sıklığının ise altı ile bir arasında olduğu görülmektedir. 61 metaforun ise birer kez kullanıldığı belirlenmiştir. Güzel Sanatlar Eğitimi Bölümü öğretmenliği bölümü öğretmen adaylarının özel gereksinimli öğrencilere yönelik geliştirdikleri metaforların kelime bulutu Şekil 1 'de gösterilmiştir. 
Tablo 2

Öğretmen Adaylarının Özel Gereksinimli Öğrencilere Yönelik Geliștirdikleri Metaforlar

\begin{tabular}{|c|c|c|c|c|c|c|c|c|}
\hline $\begin{array}{l}\text { Metafor } \\
\text { sirasi }\end{array}$ & Metafor ad 1 & $N$ & $\begin{array}{l}\text { Metafor } \\
\text { siras1 }\end{array}$ & Metafor ad 1 & $N$ & $\begin{array}{l}\text { Metafor } \\
\text { s1rasi }\end{array}$ & Metafor ad 1 & $N$ \\
\hline 1. & Çiçek & 31 & 35. & Ayrıcalıklı & 2 & 69. & Başka bir boyut & 1 \\
\hline 2. & Herkes & 24 & 36. & Hayat & 2 & 70. & $\begin{array}{l}\text { Yeşil elmalar arasındaki } \\
\text { kırmızı elmalar }\end{array}$ & 1 \\
\hline 3. & Yapboz & 9 & 37. & Şükür & 2 & 71. & İnsanüstü varlıklar & 1 \\
\hline 4. & Keşfedilmemiş ülke & 9 & 38. & Sevgi dolu & 2 & 72. & Renkler & 1 \\
\hline 5. & Melek & 7 & 39. & Bir parçam & 2 & 73. & Müzik & 1 \\
\hline 6. & Bebek & 7 & 40. & Farkındalık & 2 & 74. & Orman & 1 \\
\hline 7. & Özel & 7 & 41. & Gizli bahçe & 1 & 75. & Mucize & 1 \\
\hline 8. & Güçlü & 7 & 42. & Ağaç kökü & 1 & 76. & Yeşerememiş tohum & 1 \\
\hline 9. & Kapalı kutu & 7 & 43. & Dağ & 1 & 77. & $\begin{array}{l}\text { Hayat güzelliklerini } \\
\text { yansıtan çiçek }\end{array}$ & 1 \\
\hline 10. & Yardıma muhtaç & 7 & 44. & Bahar & 1 & 78. & Bulut & 1 \\
\hline 11. & Masumiyet & 6 & 45. & Y1k1lmaz kaya & 1 & 79. & Yildiz & 1 \\
\hline 12 & Umut & 6 & 46. & Tülbent & 1 & 80. & Kafesteki kuş & \\
\hline 13. & Temiz kalpli & 5 & 47. & Önemli & 1 & 81. & Iş1k & 1 \\
\hline 14. & Ağaç & 5 & 48. & Kristal & 1 & 82. & Su şişesi & 1 \\
\hline 15. & Keşfedilmemiş gezegen & 4 & 49. & Labirent & 1 & 83. & Çiçek bahçesi & 1 \\
\hline 16. & Mücevher & 4 & 50. & Bulmaca & 1 & 84. & Uğur böceği & 1 \\
\hline 17. & Empati & 4 & 51. & Okunmamış mektup & 1 & 85. & Okyanus & 1 \\
\hline 18. & Kanadı kırık kuş & 4 & 52. & Farklı bir fikir & 1 & 86. & Toplumun 1şı̆ğ & 1 \\
\hline 19. & Değerli & 4 & 53. & Y1ldiz & 1 & 87. & Bir elin beş parmamğ 1 & 1 \\
\hline 20. & Kapalı kutu & 3 & 54. & Köprü & 1 & 88. & $\begin{array}{c}\text { Eğitimin } \\
\text { vazgeçilmezleri }\end{array}$ & 1 \\
\hline 21. & Hayatın gerçeği & 3 & 55. & $\begin{array}{c}\text { Kuru dalda filizlenen } \\
\text { yaprak }\end{array}$ & 1 & 89. & Kirlenmemiş okyanus & 1 \\
\hline 22. & Dünya & 3 & 56. & Ceviz & 1 & 90. & Daha özel & 1 \\
\hline 23. & Mücadele & 3 & 57. & Gökyüzü & 1 & 91. & Önemli & 1 \\
\hline 24. & Matruşka & 2 & 58. & Soyut bir dünya & 1 & 92. & İlgiye muhtaç & 1 \\
\hline 25. & Kitap & 2 & 59. & Gizli hazine & 1 & 93. & Yarım kalmış beste & 1 \\
\hline 26. & Vazo & 2 & 60. & Yeni bir hayat & 1 & 94. & Sorumluluk & 1 \\
\hline 27. & Kelebek & 2 & 61. & Mucize & 1 & 95. & Şeffaf kafes & 1 \\
\hline 28. & Yavru kuş & 2 & 62. & Ayna & 1 & 96. & Fidan & 1 \\
\hline 29. & Okunmamış kitap & 2 & 63. & Gökkuşağ1 & 1 & 97. & Kedi & 1 \\
\hline 30. & Hammadde & 2 & 64. & Saks1 & 1 & 98. & Bebeğin anne demesi & 1 \\
\hline 31. & Cevher & 2 & 65. & Palet & 1 & 99. & Kuş & 1 \\
\hline 32. & Yetenek & 2 & 66. & $\begin{array}{l}\text { Fırçada sürülmeyi } \\
\text { bekleyen boya }\end{array}$ & 1 & 100. & Susuz kalmış ağaç & 1 \\
\hline 33. & Farklı dünya & 2 & 67. & Parmak izi & 1 & 101. & Özveri ve sabır & 1 \\
\hline 34. & $\mathrm{Su}$ & 2 & 68. & Tanrının emaneti & 1 & 102. & Yaralı kaplan & 1 \\
\hline
\end{tabular}


Tablo 2’de görüldüğü gibi, Güzel Sanatlar Eğitimi Bölümü öğretmen adayları özel gereksinimli öğrencilere ilişkin 102 adet metafor üretmiş ve üretilen metaforlar öğretmen adaylarının kullanım sıklıklarına göre verilmiştir. $\mathrm{Bu}$ metaforlardan öğretmen adaylarının en fazla kullanılan çiçek (31), herkes (24), yapboz (9), keşfedilmemiş ülke (9), melek (7), bebek (7), özel (7), güçlü (7), kapalı kutu (7) ve yardıma muhtaç (7) olduğu görülmektedir. Öğretmen adaylarının kullandıkları sonraki metaforların sıklığının ise altı ile bir arasında olduğu görülmektedir. 61 metaforun ise birer kez kullanıldığı belirlenmiştir. Güzel Sanatlar Eğitimi Bölümü öğretmenliği bölümü öğretmen adaylarının özel gereksinimli öğrencilere yönelik geliştirdikleri metaforların kelime bulutu Şekil 1 'de gösterilmiştir.

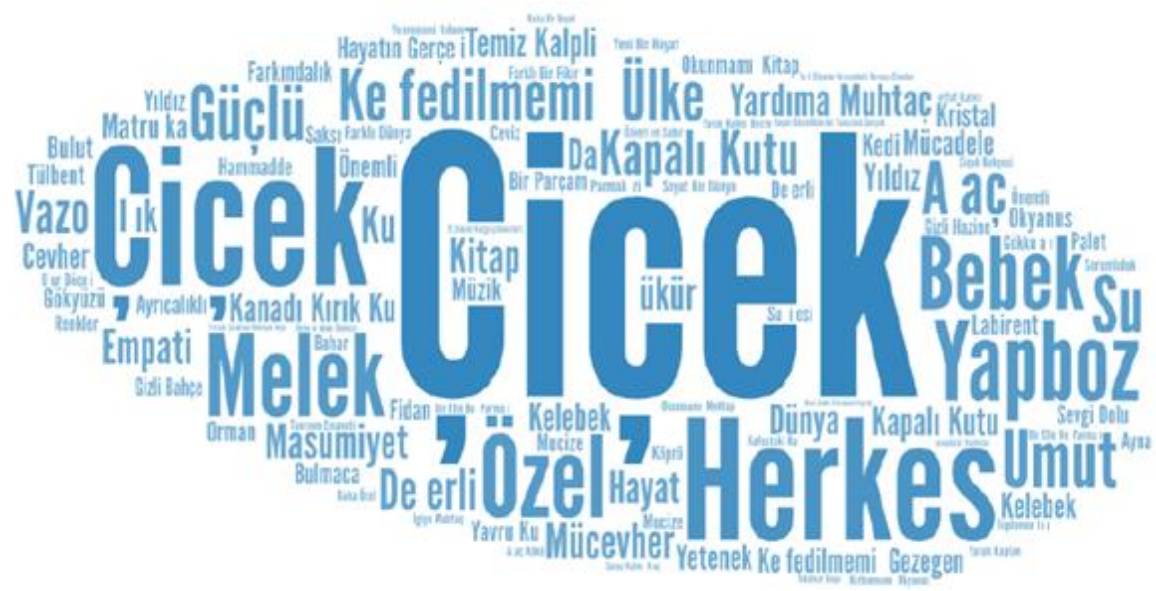

Şekil 1. Güzel Sanatlar Eğitimi Bölümü öğretmen adaylarının özel gereksinimli öğrencilere yönelik geliştirdikleri metaforlara ait kelime bulutu.

Şekil 1'de görüldüğü gibi öğretmen adayları en fazla çiçek, melek, özel, herkes, yapboz ve melek gibi metaforlar üretmişlerdir. Öğretmen adaylarının ürettikleri metaforlar incelendiğinde Güzel Sanatlar Eğitimi Bölümü öğretmen adaylarının özel gereksinimli öğrencileri daha çok hayatın güzel yönünü görmeyi sağlayan iyimser duygularla ilişkilendirdiği görülmektedir.

\section{İkinci Alt Amaca İlişkin Bulgular}

Güzel Sanatlar Eğitimi Bölümü öğretmen adaylarının özel gereksinimli öğrencilere ilişkin 102 metafor üretmişlerdir. Üretilen metoforlar ortak özellikleri ve kullanım gerekçelerine göre gruplandırılmıştır. Gruplandırmaların sonucunda, metaforlar sekiz farklı kategoride toplanmış ve bu kategoriler Şekil 2'de verilmiştir. 

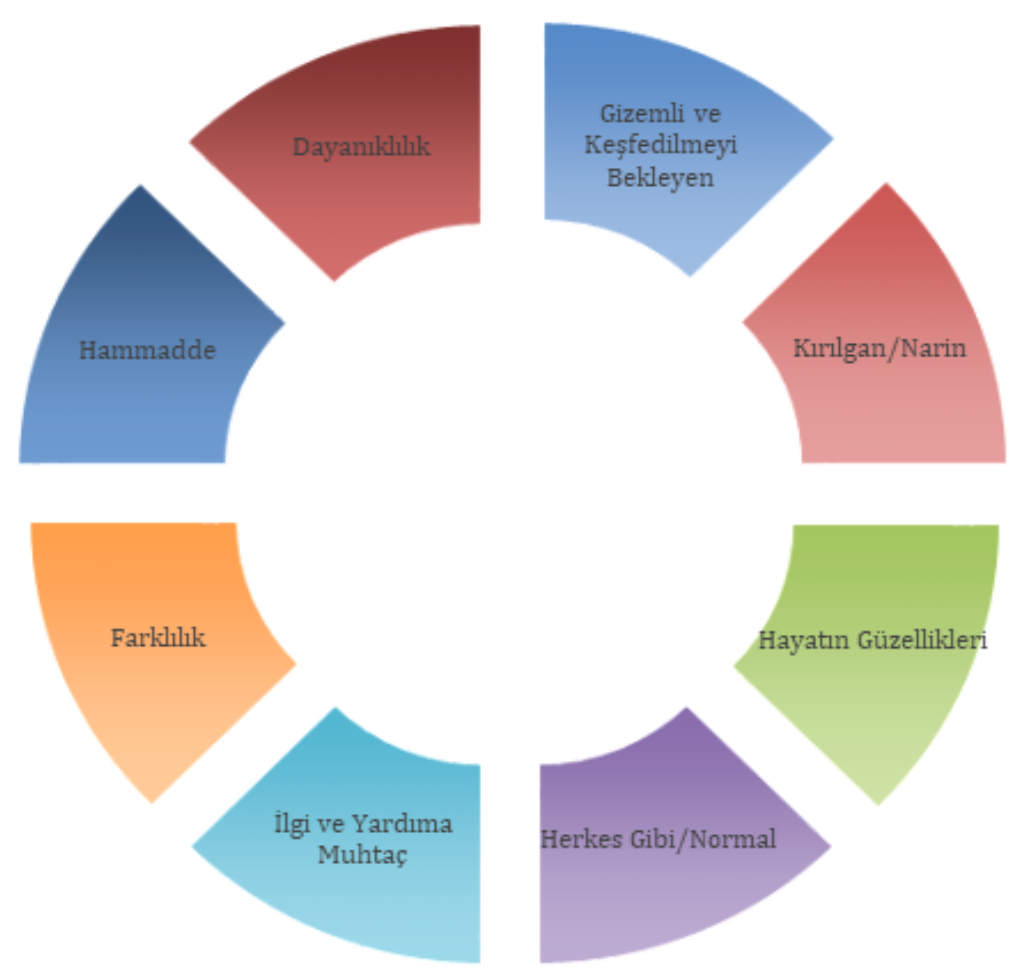

Şekil 2. Güzel Sanatlar Eğitimi Bölümü öğretmen adaylarının özel gereksinimli öğrencilere yönelik alg1 kategorileri.

Şekil 2’ye bakıldığında Gazi Eğitim Fakültesi Güzel Sanatlar Eğitimi Bölümü öğretmen adaylarının özel gereksinimli öğrencilere ilişkin ürettikleri metaforların "Gizemli ve keşfedilmeyi Bekleyen”, "Kırılgan/Narin”, "Hayatın Güzellikleri”, "Herkes Gibi/Normal”, "İlgiye ve Yardıma Muhtaç", "Farklılık", "Hammadde" ve "Dayanıklılık" kategorilerinin altında toplandığı görülmektedir. Bu kategorilere yönelik metaforlar ve öğretmen adayı görüşleri tablolar halinde aşağıda sunulmuştur. Öğretmen adaylarının "gizemli ve keşfedilmeyi bekleyen" kategorisine yönelik görüşlerinden örnekler Tablo 3'te verilmiştir.

Tablo 3

Gizemli ve Keşfedilmeyi Bekleyen Kategorisine Ait Kodlar ve Açıklama Örnekleri

\begin{tabular}{|c|c|}
\hline Metafor ad1 & Açıklama örnekleri \\
\hline Keşfedilmemiş ülke & $\begin{array}{c}\text { "Yapabilecekleri birçok şey vardır ve bunların bilinçli kişiler tarafından ortaya çıkarılması } \\
\text { gerekir." (ÖA72) }\end{array}$ \\
\hline Yapboz & “Anlaşılması güç, ancak anlaşıldıklarında çok eğlenceli öğrencilerdir.” (ÖA90) \\
\hline Kapalı kutu & "Dışarıdan ne olduğu, içinde ne gibi güzellikler barındırdığı bilinmez." (ÖA48) \\
\hline Keşfedilmemiş gezegen & “Onların eksikliklerinden çok bilinmeyen birçok özel yetenekleri var.” (ÖA10) \\
\hline Okunmamış kitap & “Görünüşe bakıp okumazsın ama içeriği çok güzeldir.” (ÖA25) \\
\hline Kitap & "Okuyarak anlayabilirsin.” (ÖA99) \\
\hline Matruşka & “İçlerinden her defasında yeni bir dünya açılır.” (ÖA13) \\
\hline Okyanus & $\begin{array}{c}\text { "Yüzmesini bilen sonsuz derinliklerine kadar gidebilir, bilmeyen insanı ise bir avuç suda } \\
\text { boğabilir." (ÖA49) }\end{array}$ \\
\hline Bulmaca & $\begin{array}{c}\text { “İçlerinde ne yetenekler saklı olduğunu çözmeye çalışmadan ve anlamaya çalışmadan asla } \\
\text { bilemeyiz." (ÖA62) }\end{array}$ \\
\hline
\end{tabular}


Tablo 3 (devami)

\begin{tabular}{|c|c|}
\hline Metafor ad 1 & Açıklama örnekleri \\
\hline Gökyüzü & "Çok geniş bir evren.” (ÖA149) \\
\hline Soyut bir dünya & "Onları anlamak, kendimizi onların yerine koyabilmek oldukça zordur." (ÖA8) \\
\hline Gizli hazine & “Engelli olmak onları mahkûm bırakmak değil içindeki hazineyi keşfetmektir.” (ÖA11) \\
\hline Yeni bir hayat & "En başından beri keşfedilmemiş deneyimleri var." (ÖA44) \\
\hline Gizli bahçe & “Ancak görmek isteyenler o güzelliği keşfedebilir.” (ÖA68) \\
\hline Y1ld1z & "Yıldız gibi ışık kaynağıdır, ışık kaynağın farklılığı ile farklı kişilikler keşfetmektir." (ÖA83) \\
\hline Okunmamış mektup & $\begin{array}{c}\text { "İclerinde ne yetenekler saklı olduğunu çözmeye çalışmadan ve anlamaya çalışmadan asla } \\
\text { bilemeyiz." (ÖA16) }\end{array}$ \\
\hline Farklı bir fikir & "Bizlerden farklı düşünen insanlar." (ÖA24) \\
\hline Labirent & "Zor görünseler de onların dünyasına girince çözmesi kolay.” (ÖA30) \\
\hline
\end{tabular}

Tablo 3'te görüldüğü gibi "gizemli ve keşfedilmeyi bekleyen" kategorisi altında 18 metafor bulunmaktadır. Öğretmen adaylarının ifadelerine bakıldığında özel gereksinimli öğrencilerin gizemli ve keşfedilmeyi bekleyen özellikleri olduğuna değinilmiştir. Bu kategoride en çok "keşfedilmemiş ülke ve yapboz" metaforlarının ifade edildiği görülmektedir. Öğretmen adaylarının "kırılgan, narin” kategorisine yönelik görüşlerinden örnekler Tablo 4'te verilmiştir.

Tablo 4

Kırılgan, Narin Kategorisine Ait Kodlar ve Açıklama Örnekleri

\begin{tabular}{lc}
\hline Metafor adı & Açıklama örnekleri \\
\hline Çiçek & "Kopardığın, üzdüğün an solmaya yüz tutar ve belki bir daha açmaz." (ÖA4) \\
Vazo & "Onların yardıma, sevgiye, tutulacak bir elleri olmasına ihtiyacı vardır." (ÖA52) \\
Kelebek & "Çok narin, dikkat edilmesi gereken bireylerdir." (ÖA100) \\
Tülbent & "Hassas ve narindirler.” (ÖA125) \\
Önemli & "Engelli insanlar bir parça eksiktir ama bir parça eksik fikirler bizim gibidir.” (ÖA38) \\
Kristal & "Narin ve kırılgan özel insanlardır.” (ÖA151) \\
\hline
\end{tabular}

Tablo 4’te görüldüğü gibi “kırılgan, narin” kategorisi altında altı metafor bulunmaktadır. Öğretmen adaylarının ifadeleri incelendiğinde özel gereksinimli öğrencilerin hassas ve kırılgan özellikleri olduğuna değinilmiştir. Bu kategoride en çok "çiçek" metaforunun ifade edildiği görülmektedir. Öğretmen adaylarının "hayatın güzellikleri” kategorisine yönelik görüşlerinden örnekler Tablo 5 'te verilmiştir

Tablo 5

Hayatın Güzellikleri Kategorisine Ait Kodlar ve Açıklama Örnekleri

\begin{tabular}{|c|c|}
\hline Metafor ad1 & Açıklama örnekleri \\
\hline Çiçek & "Varlığıyla güzellik katan, hepsi rengârenk ama biraz ilgi bekleyen bireylerdir." (ÖA201) \\
\hline Masumiyet & "Yalan bilmez, kötülükten habersiz” (ÖA93) \\
\hline Melek & "Kalpleri daha saf, daha sevgi doludur. Onlar harikadır." (ÖA2) \\
\hline Umut & “Hem çok güçlüler hem de mucizelerle dolular.” (ÖA253) \\
\hline Temiz kalpli & “Asla mutlu olmaktan vazgeçmezler, hayatlarından zevk almayı bilen insanlar.” (ÖA20) \\
\hline Mücevher & “Değerli ve özeldir.” (ÖA89) \\
\hline Empati & "Her birey hayatının herhangi bir döneminde engelli olabilecek durumdadır." (ÖA147) \\
\hline Değerli & $\begin{array}{c}\text { "Bizler her ne kadar sağlıklı bireyler olarak tanımlansak da onlar da sağlıklı ve nadirdir." } \\
\text { (ÖA56) }\end{array}$ \\
\hline
\end{tabular}


Tablo 5 (devami)

\begin{tabular}{|c|c|}
\hline Metafor ad1 & Açıklama örnekleri \\
\hline $\mathrm{Su}$ & "Çok saf, temiz yürekli insanlardır." (ÖA260) \\
\hline Kirlenmemiş okyanus & $\begin{array}{c}\text { "Yüzmesine bilen sonsuz derinliklerine kadar gidebilir, bilmeyen insanı ise bir avuç suda } \\
\text { boğabilir." (ÖA138) }\end{array}$ \\
\hline Müzik & “İnsan ruhuna huzuru hatırlatırlar." (ÖA14) \\
\hline Orman & "Her biri farklı güzellikte nefes almayı öğretir, her zaman farklı bir algı yaratırlar." (ÖA63) \\
\hline Mucize & “Bizlerin yapabileceklerinin de üstünde yeteneğe sahip olabilecek insanlardır.” (ÖA131) \\
\hline $\begin{array}{l}\text { Hayat güzelliklerini } \\
\text { Yansitan gerçek }\end{array}$ & "Yetersizlikleri olmasına rağmen güzelliği ve başarıyı sağlayabildikleri için.” (ÖA53) \\
\hline Hayatın gerçeği & "Bütün zorlukları kendi başına aşmaya çalışan bireylerdir.” (ÖA174) \\
\hline Hayat & "Onlarla ilgilendikçe ve onlara yaşama dair güzel şeyler kattıkça hayat güzelleşir." (ÖA91) \\
\hline Şükür & “Zorlu mücadeleye karş1 savaşırlar.” (ÖA88) \\
\hline Sevgi dolu & "Sevgi ile eğitilen insanlardır." (ÖA70) \\
\hline Bulut & "Yumuşackk kalpleri, saf masum bir güzellikleri var.” (ÖA190) \\
\hline Yild1z & “Dünyadan görünürler, bizden çok farklıdır ama çok güzellerdir." (ÖA172) \\
\hline Iş1k & $\begin{array}{c}\text { "Merhamet dolu hareketlerle engelli olmayan bizleri aydınlatıp, çok güzel bir hatırlatma } \\
\text { yapıyorlar." (ÖA101) }\end{array}$ \\
\hline $\mathrm{Su}$ şişesi & "Ulaşmak zor ama ulaştığın zaman en güzel zaman.” (ÖA26) \\
\hline Çiçek bahçesi & "İlgilenirsen içinde renk renk çiçekler açar." (ÖA123) \\
\hline Uğur böceği & "Çok tatlı, çok masum ve çok kırılganlar bembeyaz bir papatya gibi." (ÖA40) \\
\hline
\end{tabular}

Tablo 5'te görüldüğü gibi öğretmen adaylarının "hayatın güzellikleri” kategorisinde özel gereksinimli öğrencilere yönelik oluşturdukları 24 metafor bulunmaktadır. Bu metaforlara bakıldığında öğretmen adaylarının özel gereksinimli öğrencilerin yaşamın güzel yönlerini hatırlatan, olumlu düşünmeye sevk eden yönleri olduğunu belirtmişlerdir. Bu kategoride en çok "çiçek ve melek" metaforlarının ifade edildiği görülmektedir. Öğretmen adaylarının “normal/ herkes gibi” kategorisine yönelik görüşlerindn örnekler Tablo 6'da verilmiştir.

Tablo 6

Normal/Herkes Gibi Kategorisine Ait Kodlar ve Açılama Örnekleri

\begin{tabular}{lc}
\hline Metafor adı & Açılama örnekleri \\
\hline Herkes & "Farklı değiller ve topluma kazandırılmalılar." (ÖA240) \\
$\begin{array}{l}\text { Dünya } \\
\text { Toplumun bir parçası }\end{array}$ & "Bizlerden hiçbir farkı olmadan tüm eşitlik hak ve ortamlar sağlanmalıdır." (ÖA119) \\
Farkındalık & "Bizden hiçbir fark1 yok ve olmaması için çalışmalıyız.” (ÖA94) \\
Toplumun Işı̆̆ı & "Birbirimizden bir farkımız yoktur, bir olduğumuzda birbirimizi tamamlıoruz." (ÖA36) \\
Eğitimin vazgeçilmezleri & "Bizimle eşit imkânlara sahip olmaları çok önemlidir.” (ÖA188) \\
Bir elin beş parmağı & "Eğitim her yaşa her kesime aittir.” (ÖA187) \\
Normal & "Normal insanlardan fark1 yoktur.” (ÖA81) \\
\hline
\end{tabular}

Tablo 6'de görüldüğü gibi “normal/herkes gibi” kategorisi altında sekiz metafor bulunmaktadır. Öğretmen adaylarının ifadeleri incelendiğinde özel gereksinimli öğrencilerin özel gereksinimi olmayan öğrencilerden bir farklarının olmadığına değinilmiştir. Bu kategoride en çok "herkes" metaforunun ifade edildiği görülmektedir. Öğretmen adaylarının "ilgiye ve yardıma muhtaç” kategorisine yönelik görüşlerinden örnekler Tablo 7'de verilmiştir 
Tablo 7

Ilgiye ve Yardıma Muhtaç Kategorisine Ait Kodlar ve Açıklama Örnekleri

\begin{tabular}{|c|c|}
\hline Metafor ad1 & Açıklama örnekleri \\
\hline Bebek & "Bakıma ilgiye ve sevgiye her zaman muhtaçlardır." (ÖA71) \\
\hline Yardıma muhtaç & "Bir şeyler başarabilmek için yardıma ihtiyaçları var." (ÖA127) \\
\hline Yavru kuş & "Hak ettikleri özel ilgiyi almalı.” (ÖA69) \\
\hline Kanadı kırık kuş & "Her zaman eksiktirler ve bu yüzden yardıma ihtiyaçları vardır." (ÖA264) \\
\hline Kedi & "Sürekli ilgi ve sevgi göstermek gerekir." (ÖA202) \\
\hline Kelebek & "Çok narin, dikkat edilmesi gereken bireylerdir." (ÖA1) \\
\hline Kuş & "Eğer onunla aynı dilde anlaşırsanız her şeyi bilirsiniz." (ÖA21) \\
\hline Susuz kalmış ağaç & "Her daim yardıma ihtiyacı vardır." (ÖA195) \\
\hline Özveri ve sabır & "Diğer öğrencilere kiyasla daha zor öğrenebilirler.” (ÖA222) \\
\hline Kafesteki kuş & $\begin{array}{c}\text { "Birey gibi görülmeyip toplumdan ayrı tutularak hep birilerine muhtaçmış gibi } \\
\text { yetiştiriliyorlar." (ÖA73) }\end{array}$ \\
\hline Yeşerememiş tohum & "Göz ardı ediliyorlar, önemsenmiyorlar onlar için yapılan çalışmalar yetersiz." (ÖA168) \\
\hline İlgiye muhtaç & "Engeller aş11ır." (ÖA51) \\
\hline Yarım kalmış beste & "Eksik ama içinde bir o kadar güzellikler taşıyan umutlu." (ÖA118) \\
\hline Sorumluluk & "Biz de engelli adayı bir insanız." (ÖA175) \\
\hline Şeffaf kafes & $\begin{array}{c}\text { "Aslında etimizle kemiğimizle hepimiz aynıyızdır ama bizi birbirimizden ayıran o ince } \\
\text { şeffaf çizgilerdir." (ÖA22) }\end{array}$ \\
\hline Tanrının emaneti & "Tamamen bize bağl1lar." (ÖA183) \\
\hline Fidan & “Özel ilgi gösterilmesi gereken öğrenciler.” (ÖA213) \\
\hline Bebeğin anne demesi & "Anlaşılması çok zor görünse de aslında anlayamamamız beyin engelimizdendir." (ÖA41) \\
\hline
\end{tabular}

Tablo 7'de görüldüğü gibi “ilgiye ve yardıma muhtaç” kategorisi altında 18 metafor bulunmaktadır. Öğretmen adaylarının ifadeleri incelendiğinde özel gereksinimli öğrencilerin ilgiye ve başkalarının yardımına ihtiyaçları olduğuna değinilmiştir. Bu kategoride en çok "bebek ve yardıma muhtaç" metaforlarının ifade edildiği görülmektedir. Öğretmen adaylarının “farklılık” kategorisine yönelik görüşlerinden örnekler Tablo 8'de verilmiştir.

Tablo 8

Farklılık Kategorisine Ait Kodlar ve Açıklama Örnekleri

\begin{tabular}{|c|c|}
\hline Metafor adi & Açıklama örnekleri \\
\hline Özel & "Engellilerin özel gereksinime ve bakıma ihtiyaçları vardır." (ÖA15) \\
\hline Farkındalık & “Olağanın dışındadır.” (ÖA54) \\
\hline Parmak izi & $\begin{array}{c}\text { "Uzaktan bakıldığında birbirine benzer fakat hiçbiri birbirinin aynı değil. Biz onları } \\
\text { sınıflamaya çalışsak da onların hepsinin farklı ihtiyaçları var ve hepsi farklı yetenekleri olan } \\
\text { bireylerdir." (ÖA120) }\end{array}$ \\
\hline Yetenek & $\begin{array}{c}\text { "Engelli olan bireyler genellikle engellerine göre farklı konularda (müzik-resim vb.) çok } \\
\text { yetenekli." (ÖA230) }\end{array}$ \\
\hline Başka bir boyut & "Dünyaya farklı açıdan bakmayı sağladıkları.” (ÖA82) \\
\hline $\begin{array}{l}\text { Yeşil elmalar arasındaki } \\
\text { kırmızı elmalar }\end{array}$ & "Eşit şartlarda yaşama hakkı var.” (ÖA97) \\
\hline Farklı dünya & $\begin{array}{c}\text { "Kimisi bazı uzuvlarından yoksun olmasına rağmen yaşama dört elle tutuna } \\
\text { çabasındadırlar." (ÖA58) }\end{array}$ \\
\hline
\end{tabular}


Tablo 8 (devami)

\begin{tabular}{|c|c|}
\hline Metafor ad1 & Açıklama örnekleri \\
\hline Renkler & $\begin{array}{l}\text { "Her biri farklı renkler içerir ve o renkleri çözmek ve tuvale sürmeden önce eklememiz } \\
\text { gereken renkler var." (ÖA105) }\end{array}$ \\
\hline Daha özel & “Özel.” (ÖA59) \\
\hline Ayricalıklı & $\begin{array}{c}\text { "Beyinsel olarak daha ileri seviyededirler ve doğru eğitimle beraber çok büyük işler } \\
\text { yapabilirler." (ÖA9) }\end{array}$ \\
\hline Önemli bir yetenek & "İçlerinde çok yetenekliler var.” (ÖA66) \\
\hline Kelebek & "Özel ve kendi içinde farklı dünyaları olduğu." (ÖA79) \\
\hline Yildiz & $\begin{array}{c}\text { "Yıldızlar bizlere uzak ve farklı gelirler ama çok özeldirler parlarlar tıpkı onlar gibi. Onlar } \\
\text { yeryüzünün yıldızıdırlar." (ÖA244) }\end{array}$ \\
\hline
\end{tabular}

Tablo 8'de görüldüğü gibi “farklılık” kategorisi altında 18 metafor bulunmaktadır. Öğretmen adaylarının ifadeleri incelendiğinde özel gereksinimli öğrencilerin ilgiye ve başkalarının yardımına ihtiyaçları olduğuna değinilmiştir. Bu kategoride en çok "özel” metaforunun ifade edildiği görülmektedir. Öğretmen adaylarının "hammadde" kategorisine yönelik görüşlerinden örnekler Tablo 9' da verilmiştir.

Tablo 9

Hammadde Kategorisine Ait Kodlar ve Açılama Örnekleri

\begin{tabular}{|c|c|}
\hline Metafor ad1 & Açıklama örnekleri \\
\hline Hammadde & “Onlarda büyük cevherler var bunları ortaya çıkarmalıyı..” (ÖA106) \\
\hline Mucize & "Bizlerin yapabileceklerinin de üstünde yeteneğe sahip olabilecek insanlardır." (ÖA78) \\
\hline Ayna & "İnsanların isterse her şeyi yapabileceğinin bir kanıtıdır." (ÖA121) \\
\hline Gökkuşağ1 & $\begin{array}{c}\text { "Her çocuğun içinden çıkmak isteyen renkler vardır, önemli olan o bulutları çarptırtmak, } \\
\text { yağmuru yağdırtmaktır." (ÖA159) }\end{array}$ \\
\hline Saks1 & $\begin{array}{c}\text { “Doğru düşünceleri tohum olarak değerlendirdiğimizde özen gösterip ilgilenirsek bize } \\
\text { çiçekler verir.” (ÖA184) }\end{array}$ \\
\hline Cevher & "Kendi yeteneklerinin farkına tam olarak varamamışlardır." (ÖA42) \\
\hline Palet & "Kendi içlerinde çeşit çeşit renkler barındırır.” (ÖA57) \\
\hline $\begin{array}{l}\text { Firçada sürülmeyi } \\
\text { bekleyen boya }\end{array}$ & $\begin{array}{c}\text { "Normal bireyler kadar yetenekli çalışkan bireylerdir. Sadece fark edilmeleri ve firsat } \\
\text { verilmesi gerekiyor." (ÖA215) }\end{array}$ \\
\hline İnsanüstü varlıklar & $\begin{array}{l}\text { "Onlar ağaç gibiler kökleri ne kadar uzasa da boyları uzayıp eğilse de toprağa tutunuyorlar." } \\
\text { (ÖA23) }\end{array}$ \\
\hline \multirow{2}{*}{\multicolumn{2}{|c|}{$\begin{array}{l}\text { Tablo 9'da görüldüğ̈̈ gibi "hammadde" kategorisi altında dokuz metafor bulunmaktadır. Öğgretmen } \\
\text { adaylarının ifadeleri incelendiğinde özel gereksinimli öğrencilerin başarıyı ortaya çıkaracak bir potansiyele sahip } \\
\text { olduğu görülmektedir. Bu kategoride en çok "hammadde" metaforunun ifade edildiği görülmektedir. Öğretmen } \\
\text { adaylarının “dayanıklılık" kategorisine yönelikgörüşlerinden örnekler Tablo 10'da verilmiştir. } \\
\text { Tablo } 10\end{array}$}} \\
\hline & \\
\hline \multicolumn{2}{|c|}{ Dayanıklılık Kategorisine Ait Kodlar ve Açıklama Örnekleri } \\
\hline Metafor ad1 & Açıklama örnekleri \\
\hline Ağaç & $\begin{array}{c}\text { "Farklılıkları olsa bile o bahçeye katkısı vardır. Sadece gövdesi farklıdır belki ama sonuçta o } \\
\text { da meyve verir." (ÖA199) }\end{array}$ \\
\hline Ağaç kökü & “Aş1lmas1 en zor engelleri aşıp hayata tutunmaya çalışırlar." (ÖA261) \\
\hline Mücadele & "Yaşanılan bunca zorluğa rağmen hayata tutunmak ve bir yerlere varmak başarıdır." \\
\hline Y1k1lmaz kaya & "Her türlü zorluğu kendi başlarına yenebilirler.” (ÖA170) \\
\hline
\end{tabular}


Tablo 10 (devami)

Dayanıklılık Kategorisine Ait Kodlar ve Açıklama Örnekleri

\begin{tabular}{|c|c|}
\hline Metafor ad1 & Açıklama örnekleri \\
\hline Dağ & "Hareketleri kısıtlıdır belki ama yaptıklarıyla gözünüzde büyürler.” (ÖA19) \\
\hline Bahar & “Tüm soğuk kış günlerine rağmen insanın içini kıpırdatan tomurcuklar açar.” (ÖA75) \\
\hline Güçlü & "Her şeyin üstesinden geliyorlar ve her zorluğa karşı dimdik ayakta duruyorlar." (ÖA98) \\
\hline Köprü & "Birbirimize bağlayan bir yoldur." (ÖA107) \\
\hline $\begin{array}{l}\text { Kuru dalda filizlenen } \\
\text { Yaprak }\end{array}$ & $\begin{array}{l}\text { "Toplumumuz içerisinde çok güzel başarıyla sıyrılan ve kendilerini geliştirmiş insanlar." } \\
\text { (ÖA144) }\end{array}$ \\
\hline Ceviz & "İçe kapanık ve dış1 sert fakat onlarla arkadaş olunduğunda meyvesi yenir." (ÖA27) \\
\hline Yaralı kaplan & "Çok güçlü, hayata adapte olmuş, yarasıyla yaşayabilen sevgi dolu insanlardır." (ÖA5) \\
\hline
\end{tabular}

Tablo 10'da görüldüğü gibi “dayanıklılık” kategorisi altında 11 metafor bulunmaktadır. Öğretmen adaylarının ifadeleri incelendiğinde özel gereksinimli öğrencilerin karşılaştıkları zorluklara karşı dirençli olduklarına değinilmiștir. Bu kategoride en çok "güçlü ve ağaç" metaforlarının ifade edildiği görülmektedir.

\section{Tartışma ve Sonuç}

Bu araştırmada da Gazi Eğitim Fakültesi Güzel Sanatlar Eğitimi Bölümü öğretmen adaylarının özel gereksinimli öğrencilere yönelik geliştirdikleri metaforların incelenmesi amaçlanmıştır. Araştırmada elde edilen verilere göre 267 Güzel Sanatlar Eğitimi Bölümü öğretmen adayının özel gereksinimli öğrencilere ilişkin "Gizemli ve Keşfedilmeyi Bekleyen", "Kırllgan/Narin", "Hayatın Güzellikleri”, "Herkes Gibi/Normal”, "İlgiye ve Yardıma Muhtaç", "Farklılık", "Hammadde" ve "Dayanıklılık" olmak üzere sekiz kategoride 102 metafor ürettiği görülmüştür. Öğretmen adaylarının ürettikleri meteforlar incelendiğinde önemli bir kısmının özel gereksinimli öğrenciyi “çiçek, herkes, yapboz, keşfedilmemiş ülke, melek ve bebek” olarak algıladığı görülmektedir. Bu metaforlar, öğretmen adaylarının özel gereksinimli öğrencileri nasıl algıladıklarını, özel gereksinimli öğrencilere yönelik tutumlarını ve inançlarını ya da deneyimlerini vb. metaforlar aracılığıyla farklı kavramlarla açıkladıklarını göstermektedir (Aubusson, 2002; Ekici, 2016). Özellikle "hayatın güzellikleri" kategorisinde diğer kategorilerdeki metaforlardan en fazlasını (24 metafor) ürettikleri görülmektedir. Bu kategoriler ve diğer kategorilerde üretilen metaforların çoğunluğunun olumlu olduğu, öğretmen adaylarının özel gereksinimli öğrencileri daha çok hayatın güzel yönünü görmeyi sağlayan iyimser duygularla ilişkilendirdiği söylenebilir. Alan yazında özel gereksinimli öğrenciler hakkında metaforik algıyı değerlendiren bir araştırmaya rastlanmamakla birlikte farklı bölümlerde okuyan öğretmen adaylarının özel gereksinimli öğrencileri nasıl algıladıklarına yönelik yapılan çalışmaların sonuçları, bu çalışmanın sonuçlarıyla benzerlik göstermektedir. Vural, Esentaş ve Işıkgöz (2018) yılında Engellilerde Egzersiz ve Spor Eğitimi bölümü öğretmen adaylarının engellilere yönelik tutumlarını araştırdıkları çalışmanın sonucunda öğrencilerin engellilere yönelik olumlu tutum içerisinde oldukları bulunmuştur. Benzer şekilde Impecoven-Lind (2004) öğretmen adaylarının özel gereksinimli öğrencilere yönelik algılarını araştırdığı çalışmasında sonuçlar, öğretmen adaylarının özel gereksinimli öğrencilere yönelik algılarının oldukça olumlu olduğunu göstermiştir. Akyıldız (2017) sınıf öğretmenliği, okul öncesi ve özel eğitim bölümlerinde okuyan öğretmen adaylarının özel gereksinimli bireylere yönelik tutumlarının belirlenmesini amaçladığı çalışmasının bulgularında genel olarak öğretmen adaylarının özel gereksinimli öğrencilere yönelik tutumlarının olumlu olduğunu saptamıştır. Yaralı ise (2015) yılında öğretmen adaylarının özel gereksinimli bireylere yönelik tutumlarını bazı değişkenler açısından incelediği çalışmada Türkçe, sosyal bilgiler ve sınıf öğretmenliği ile eğitim bilimleri (PDR) bölümlerinde okuyan 209 öğretmen adayına uygulanan “özel gereksinimli bireylere yönelik tutum ölçeği” sonucunda öğretmen adaylarının özel gereksinimli bireylere yönelik beğeni boyutunun ve duyarlılıklarının nispeten yüksek, özel gereksinimli bireylere yönelik olumsuz tutumlarının ise nispeten düşük olduğunu bulgulamıştır. 
Öğretmen adayları tarafından geliştirilen metaforların 61 'i, yarıya yakını bir kez yazılmıştır. Bu veri bireysel deneyimlerin farklı metaforların oluşturulmasında önemli bir etken olduğunu göstermektedir (Cisek, 1999). Dolayısıyla araştırmaya katılan öğretmen adaylarının bireysel deneyimlerinin ve yaratıcılıklarının zengin olduğunu düşündürmektedir. Bununla birlikte Impecoven-Lind (2004) çalışmasına öğretmen adaylarının özel gereksinimli öğrencilere yönelik algılarının öğretmen adaylarının tamamladığı erken çocukluk, ilköğretim, ortaöğretim gibi alan deneyimlerine göre gruplar arasında farklılıklar olduğunu belirtmiş̧tir. Ayrıca öğretmen adaylarının özel gereksinimli öğrencilere yönelik mevcut algılarını şekillendiren faktörlerden en yaygın olanları arasında okul, uygulamalı deneyimler olduğunu ifade etmiştir. Dolayısıyla bu araştırmada elde edilen bulgulardaki öğretmen adaylarının özel gereksinimli öğrencilere karșı olumlu tutumlarının öğretmenlikleri sırasında da devam etmesi için üniversite sınıflarında aldıkları iki saatlik "özel eğitim ve kaynaştırma" dersine ek olarak özel gereksinimli öğrencilere yönelik nasıl uyarlama yapacakları, davranış yönetimi vb. konularda, biri mutlaka uygulama olmak üzere en az iki ders daha almaları önerilebilir. Çünkü özel eğitime gereksinim duyan çocukların farklı1ıklarının olumlu algılanması kadar, bu farklılıklara yönelik nasıl bir eğitim yapıldığı, çocuğun okuldaki ve okul sonrasındaki başarısı üzerinde önemli bir etkiye sahip olmaktadır (Heward vd., 2017).

"Hammadde" ve "gizemli ve keşfedilmeyi bekleyen" kategorilerinde öğretmen adaylarının geliştirdikleri metaforlar ve gerekçeleri birbiriyle benzer olsa da farklı özellikler barındırdığı için iki ayrı kategoride ele alınmıştır. "Hammadde" kategorisinde öğretmen adayları daha çok onların da belli düzeylerde potansiyelleri olduğuna yönelik metafor ve gerekçeli ifadeler kullanmışlardır. "Gizemli ve keşfedilmeyi bekleyen" kategorisinde ise özel gereksinimli öğrencilerin yetersizliklerinin ötesinde farklı özellikler barındırabildiğini ve bunun ortaya çıkarılmasına yönelik metafor ve gerekçeli ifadeler kullandıkları görülmektedir. Sonuç olarak her iki kategoride de öğretmen adaylarının özel gereksinimli öğrencilerin potansiyelleri temel alınarak bunların ortaya çıkarılmasına ve geliştirilmesine yönelik olumlu düşüncelere sahip oldukları söylenebilir. Fakat bu potansiyellerin nasıl ortaya çıkarılacağına dair bir ifade kullanmadıkları görülmektedir. Bu verilerden Güzel sanatları bölümü öğretmen adaylarının özel gereksinimli öğrencilere resim, müzik derslerini nasıl yürüteceklerinin, özel gereksinimli öğrencilerde var olduğunu düşündükleri potansiyelleri nasıl ortaya çıkaracaklarının öğretilmesinin gerekli olduğu söylenebilir. Çünkü ögretmen adaylarının öğretmenlikleri sırasında özellikle de çalışma alanları özel eğitim okulları ya da özel eğitime ihtiyaç olan çocukların da bulundukları okullar olduğunda bu bilgiye ihtiyaçları olacağı düşünülmektedir. Örneğin, Çetin (2004) özel eğitim alanında çalışan farklı meslek grubu eğitimcilerin yaşadıkları güçlükleri belirlemeyi amaçladığı çalışmasında, çeşitli eğitim uygulama ve özel eğitim ve rehabilitasyon merkezlerinde görev yapan farklı bölümlerden mezun olan eğitimcilerin, hizmet öncesi eğitimlerinde özel eğitimle ilgili yeterli teorik bilgi almamaları, uygulama yapmamaları, problem davranışları yönetmede sıkıntı yaşamaları, özel gereksinimli öğrencileri nasıl değerlendireceklerini bilememeleri, farklı öğretim yöntemlerini kullanmayla ilgili yetersiz kalma gibi güçlükler yaşadıklarını belirtmiştir. Ayrıca bu eğitimcilerin özel eğitim alana yönelik yazılı kaynak ve materyal ile hizmet içi eğitime ihtiyaç duydukları da araştırmanın bulguları arasında yer almıştır. Shippen ve diğerleri (2005) ise yaptıkları çalışmada öğretmen adaylarının, özel eğitime giriş kursunun tamamlanmasından sonra öğretmen adaylarının, genel eğitim ortamlarında özel gereksinimli öğrencilere hizmet etme konusundaki kaygı ve bu durumu kabul etmeme düzeylerini önemli ölçüde azalttı̆̆ını göstermiş̧ir. Dolayısıyla araştırmada elde edilen verilere göre öğretmen adaylarının olumlu düşüncelerinin hizmet öncesi eğitimde alacakları özel eğitim dersine ek dersler ve uygulama ile de desteklenmesi önerilmektedir. Çünkü her zaman olumlu yöndeki algı tek başına birşeyler yapmak için yeterli olmayabilir.

Öğretmen adayları "farklılı" kategorisinde 18 metafor üretirken bu kategori ile zıt olabilecek "normal/herkes gibi" kategorisinde 8 metafor üretmiştir. "Farklllık" kategorisindeki metaforlar incelendiğinde "önemli bir yetenek, parmak izi, yeşil elmalar arasındaki kırmızı elmalar" gibi daha çok bu öğrencilerin engellerinin yanı sıra özel yetenekleri açısından farklılıklara vurgu yapıldığı görülmektedir. Öğretmen adaylarının farklılıkları olumlu algılaması öğretmenlik mesleğinde karşılaşacakları öğrencilere yönelik davranışlarını da olumlu yönde etkileyeceğini düşündürmektedir. "Farklılık" kategorisinde yer alan "ayrıcalıklı, renkler, özel" gibi metaforlar ve gerekçeleri incelendiğinde ise özel gereksinimli öğrencilerin farklılıklarına yönelik eğitim verilmesi gerekliliğinin vurgulandığı görülmektedir. Özel eğitime gereksinim duyan çocuklar normal gelişim gösteren 
çocuklardan farklı olduklarından daha çok benzer olsalar da özel eğitime gereksinim duyan bir çocuk aynı yaştaki normal gelişim gösteren akranlarından önemli şekillerde ayrılmaktadır (Heward vd., 2017). Öğretmen adaylarının bu kategorideki metaforları açıklamak için kullandıkları gerekçeler özel gereksinimli öğrencilerin farklı eğitim gereksinimlerinin farkında oldukları izlenimini vermektedir. "Normal/herkes gibi" kategorisindeki metaforlar ve gerekçeleri incelendiğinde aslında öğretmen adaylarının özel gereksinimli öğrencileri engelliklerinin yanı sıra öncelikle insani ve vatandaş olma özellikleri açısından ele alarak farklılıklarıyla birlikte toplumun bir üyesi olma konusuna dikkat çeken ifadeler kullanmışlardır. Bu ifadeler dünyada ve Türkiye'de özel eğitime gereksinimi olan bireyler için özel eğitim hizmetlerine yön vermede etkili olan normalleştirme ilkesini akla getirmektedir. Normalleştirme ilkesi, özel gereksinimli olan bireylerin, toplumun diğer bireylerinin toplumda yararlandığı hak ve olanaklardan eşit düzeyde yararlanmalarını hedeflemektedir (Akçamete, 2009; Kargın, 2004; Lindsay, 2003; Ysseldyke, Algozzine \& Thurlow, 2000). Bu ilkeye dayanarak dünyada "bütünleştirme ve kaynaştırma" uygulamaları yapılmaktadır. Bu araştırmada bir değişken olarak özel eğitim dersi alma ve almama durumlarına yer verilmemesine rağmen araştırmaya katılan son sınıf öğretmen adayları arasında "özel eğitim ve kaynaştırma" dersi alan öğretmen adayları da bulunmaktadır. Öğretmen adaylarının bu kategorideki metaforları açıklamada kullandıkları gerekçelerin "özel eğitim ve kaynaştırma" dersinin bir sonucu olduğu düşünülebilir. Benzer şekilde Şahin ve Güldenoğlu (2013) yaptıkları araştırmada üniversite öğrencilerine özel eğitim ve kaynaştırmaya yönelik sunulan eğitim programının üniversite öğrencilerinin engellilere yönelik tutumları üzerinde olumlu etkileri olduğunu belirtmiştir.

Öğretmen adayları tarafından altı metafor üretilen "kırılgan ve narin" kategorisi ile 11 metafor üretilen "dayanıklılık" kategorisi de birbirine zıt görünen kategorilerdir. "Kırılgan ve narin" kategorisi için geliştirilen metaforlar incelendiğinde hayatta zarar görmemesi için hassas davranmamız gereken çiçek, kristal, kelebek gibi varlıklar olduğu görülmektedir. Bu bakış açısı öğretmen adaylarının özel gereksinimli öğrencilerin engellerinden dolayı psikolojik olarak daha hassas yapıda olabileceklerini düşündükleri izlenimini vermektedir. Ancak bu durumun engellilere özgü bir durum olmaması gerektiği ve aslında insani bir özellik olduğunun düşünülmesi gerekliliğini ortaya koymaktadır. Bir çocuğun duygu dünyası sadece onun yapısal özelliğinin doğal bir göstergesi olmayıp deneyim ve öğrenme sonucunda ortaya çıkan sosyal bir yapılanmadır. Yani eğer bir çocuk çevresindekilerin davranışları ve iletişimini anlayamıyor ve yorumlayamıyorsa bu durum çocuğun duygusal gelişimi üzerine uzun dönemli sosyal sonuçlar oluşturabilir. Sonuçta bu durum sosyal olarak değiştirilebilir (Kirk, Gallagher \& Coleman, 2015). Diğer taraftan "dayanıklılık" kategorisindeki metaforlar incelendiğinde hayatta güçlü kavramını tanımlamak için kullandığımız mücadele, yıkılmaz kaya gibi terimler ve dağ, ağaç, ağaç kökü gibi varlıkların kullanıldığı görülmektedir. Öğretmen adaylarının özel gereksinimli öğrencilerin engellerine rağmen hayata ve hayatta karşılaştıkları zorluklara karşı güçlü olabildiklerine yönelik düşünceleri, kullandıkları metaforların gerekçeli ifadelerinden anlaşılabilmektedir. Öğretmen adaylarının dayanıklılık kategorisinde ürettikleri metaforlar ve gerekçeli ifadeler özllikle bu araştırma açısından önemli sonuçlar ortaya çıkarmaktadır.

“İlgiye ve yardıma muhtaç” kategorisi incelendiğinde öğretmen adaylarının 18 metafor geliştirdikleri görülmektedir. Bu kategorideki metafor ve metaforların gerekçeleri incelendiğinde sonuçlar, Tortop ve diğerleri (2015) öğretmen adaylarının zihinsel özel gereksinimli birey kavramına ilişkin algılarını ortaya çıkarmayı hedefledikleri araştırmanın sonucunda ortaya çıkan temalarda ilk beş sırada yer alan "sosyal yaşantısı engellenmiş birey", "birtakım becerileri yerine getiremeyen birey", "ilgiye ihtiyac1 olan birey" sonucuyla benzerlik göstermektedir. Bu kategoride öğretmen adaylarının özel gereksinimli öğrencilerin ilgi, yardıma muhtaç olma durumlarını farklı metaforlar ve gerekçelerle açıkladıkları görülmektedir. Örneğin "bebek, yardıma muhtaç, kedi, kelebek, susuz kalmış ağaç, tanrının emaneti” gibi metaforların gerekçeli ifadelerinde ilgi ve yardım durumunun her zaman yapılması gerektiğini açıklarken, "kafesteki kuş, yeşerememiş tohum, bebeğin anne demesi" gibi metaforların gerekçeli ifadelerinde muhtaç olma durumunun sürekliliğini diğer kişilere ve onlara sunulan hizmetlerle açıklamışlardır. Bu kategoride ilgi ve yardım durumunun sürekli olması gerektiği düşüncesine sahip öğretmen adaylarının özel gereksinimli öğrenciler hakkında yeterince bilgi ve deneyime sahip olmadıkları düşünülebilir. Muhtaç olma durumunun sürekliliğini diğer kişilere ve onlara sunulan hizmetlerde olduğu düşüncesine sahip öğretmen adaylarının öğretmenlik yaşantısı sırasında engelleri ortadan kaldıracak önlemleri 
alabileceği düşünülmektedir. Çünkü yetersizlik durumu kişiye özel bir durumken engellilik durumu ortama ve sunulan hizmetlere göre değişiklik gösterebilmektedir (Heward vd., 2017). "Tanrının emaneti" metaforu da öğretmen adaylarının algılarını dini inançların etkilediğini düşündürmektedir. Benzer şekilde Impecoven-Lind (2004) çalışmasında öğretmen adaylarının özel gereksinimli öğrencilere yönelik mevcut algılarını şekillendiren faktörlerden en yaygın olanları arasında dini inançların da olduğunu belirtmiştir.

Sonuç olarak araştırmadan elde edilen veriler öğretmen adaylarının oluşturdukları metaforların olumlu yönde olduğunu göstermektedir. Bu ileride öğretmen olacak bir öğretmen adayı için çok önemli bir özellik olmasına rağmen alan yazın okulda ve okul dışındaki hayatlarında özel gereksinimli öğrencileri başarıya ulaştırmada, farklılıkların olumlu algılanmasının yanı sira bu farklılıklara uygun eğitim ortamlarının oluşturulmasının gerektiği yönündedir. Dolayısıyla özellikle öğretmen adaylarının üniversite sınıflarında özel gereksinimli öğrencilere yönelik teorik derslerin yanı sıra uygulamalı derslerle de desteklenmesi önerilmektedir. İleri araştırmalarda Güzel Sanatlar Eğitimi Bölümü öğretmen adaylarını bir özel gereksinimli öğrenci grubuna öğretim desenleyerek öğretim yapma becerileri ve bu sürece yönelik düşüncelerinin araştırıldı̆̆ araştırmaları yapılabilir. Bu araştırmada öğretmen adaylarının özel eğitim dersi alma ve almama ile özel gereksinimli yakını olma ve olmama değiş̧kenleri dikkate alınmamıştır. Bu değişkenler dikkate alınarak öğretmen adaylarının özel gereksinimli öğrencilere yönelik metaforik algılarının karşılaşııııldı̆̆ başka araştırmalar yapılabilir. Son olarak, Özel Eğitim Bölümü öğretmen adayları ile Güzel Sanatlar Eğitimi Bölümü öğretmen adaylarının özel gereksinimli öğrencilere yönelik metaforik algıları karşılaştırılabilir. 


\section{Kaynaklar}

Akçamete, G. (Ed.). (2009). Geleneksel eğitim okullarında özel gereksinimi olan öğrenciler ve özel ĕ̌itim [Students with special needs and special education in traditional education schools] (2. bask1). Ankara: Kök Yayıncılık.

Akyıldız, S. (2017). Öğretmen adaylarının engelli bireylere yönelik tutumlarının incelenmesi [Examination of the teacher candidates' attitudes towards people with disabilities]. Sosyal Politika Çalışmaları Dergisi, 17(39), 141-169. doi:org/10.21560/spcd.vi.338158

Anılan, B. (2017). Fen bilimleri öğretmen adaylarının kimya kavramına ilişkinin metaforik algıları [Preservice science teachers metaphoric perceptions about chemistry concept]. Eğitimde Nitel Araştırmalar Dergisi, 5(2), 7-27. doi: 10.14689/issn.2148-2624.1.5c2s1m

Arslan, M. M., \& Bayrakçı, M. (2006). Metaforik düşünme ve öğrenme yaklaşımının eğitim öğretim açısından incelenmesi [An examinatıon of metaphorical thinking and learning from educational view]. Milli Eğitim, 35(171), 100-108.

Ateş, M., \& Karatepe, A. (2013). Üniversite öğrencilerinin çevre kavramına ilişkin algılarının metaforlar yardımıla analizi [The analysis of University students' perceptions towards "environment" concept with the help of metaphors]. The Journal of Academic Social Science Studies, 6(2), 1327-1348. doi: 10.9761/jasss_630

Aubusson, P. (2002). Using metaphor to make sense and build theory in qualitative analysis. The Qualitative Report, 7(4), 1-14.

Büyükalan-Filiz, S., \& Türkmenli, A. (2019). Yaygın eğitim kurslarına katılan kursiyerlerin resim yapmaya ilişkin metaforik alg1lar1 [Metaphorical perceptions of participants to non-formal training courses on drawing]. Sosyal Bilimler Arastırmaları Dergisi, 9(2), 375-389.

Büyüköztürk, Ş., Çakmak, E., Akgün, Ö. E., Karadeniz, Ş., \& Demirel, F. (2016). Bilimsel araştırma yöntemleri [Scientific research methods] (22. bask1). Ankara: Pegem A Yayınc1lık.

Cavkaytar, A. (2017). Özel eğitime gereksinim duyan çocuklar ve özel eğitim. İ. H. Diken (Ed.), Özel eğitim gereksinimi olan ögrenciler ve özel ĕgitim [Students with special education needs and special education] içinde (ss. 3-29). Ankara: Pegem Akademi.

Cisek, P. (1999). Beyond the computer metaphor: Behaviour as interaction. Journal of Consciousness Studies, 6(11-12), 125-42.

Creswell, J. W. (2007). Research design: Qualitative, quantitative, and mixed methods approaches. California: Sage Publications Inc.

Çetin, Ç. (2004). Özel eğitim alanında çalışmakta olan farklı meslek grubundaki eğitimcilerin yaşadığı güçlüklerin belirlenmesi [Identify the difficutties educators of different professions working in the area of special education came across]. Ankara Üniversitesi Eğitim Bilimleri Fakültesi Özel Ĕ̆itim Dergisi, 5(1), 35-46.

Çitil, M., Karakoç, T., \& Küçüközyiğit, M. S. (2018). Özel eğitim lisans dersinin öğretmen adaylarının bilgi düzeylerine ve engellilere yönelik tutumlarına etkisi [The effect of special education undergraduate course to the teacher candidates' knowledge level and attitudes towards the disability]. Abant İzet Baysal Üniversitesi Ë̆itim Fakültesi Dergisi, 18(2), 815-833. doi: 10.17240/aibuefd.2018-431449

Çolak, M., \& Çetin, C. (2014). Öğretmenlerin engelliliğe yönelik tutumları üzerine bir araştırma [A research on teachers' attitudes towards disability]. Dokuz Eylül Üniversitesi İktisadi İdari Bilimler Fakültesi Dergisi, 29(1), 191-211 
Derman, A. (2014). Lise öğrencilerinin kimya kavramına yönelik metaforik algıları [High school students' metaphoric perceptions for the concept of chemistry]. Electronic Turkish Studies, 9(5), 749-776.

Döş, İ. (2010). Aday öğretmenlerin müfettişlik kavramına ilişkin metafor algıları [Metaphoric perceptions of candidate teachers to the concept of inspectors]. Gaziantep Üniversitesi Sosyal Bilimler Dergisi, 9(3), 607-629.

Draaisma, D. (2007). Bellek metaforlart: Zihinle ilgili fikirlerin tarihi [Metaphors of memory: A history of ideas about the mind] (3. baskı). (G. Koca, Çev.). İstanbul: Metis Yayınları. (Orijinal kitabın yayın tarihi 1995)

Ekici, G. (2016). Öğretmen adaylarının "Bilgisayar" kavramına ilişkin metaforik algıları [Student-teachers' metaphoric perceptions towards the concept of "computer"]. Gaziantep Üniversitesi Sosyal Bilimler Dergisi, 15(3), 755-781.

Eraslan, L. (2011). Sosyolojik metaforlar [Sociological metaphors]. Akademik bakış dergisi, 27, 1-22.

Ertemin, B. (1997). İlköğretim okulları resim-iş ögretim programı'nın değerlendirilmesi [Evaluation of primaryschool art teaching program] (Yüksek lisans tezi, Anadolu Üniversitesi). http://libra.anadolu.edu.tr/tezler/1997/125787.pdf adresinden edinilmiştir.

Gedik, N. (2016). Eğitimde üretim tabanlı çalışmalar için nitel araştırma yöntemleri. M. Y. Özden \& L. Durdu (Ed.), Olgubilim (Fenomenoloji) [Phenomenology] içinde (ss. 37-47). Ankara: Anı Yayıncılık.

Heward, W. L., Alber-Morgan, S., \& Konrad, M. (2017). Revel for exceptional children: An introduction to special education with loose-leaf version. Pearson.

Houser, J. (2015). Nursing research: Reading, using, and creating evidence. (3rd ed.). Burlington: Jones ve Bartlett Learning.

Impecoven-Lind, L. S. (2004). Preservice teachers' perceptions of students with disabilities (Unpublished dissertation, Iowa State University) Retrived from https://lib.dr.iastate.edu/cgi/viewcontent.cgi?article=1798\&context=rtd (UMI Number: 3136332)

Kargın, T. (2004). Kaynaştırma: Tanımı, gelişimi ve ilkeleri [Inclusion: Definition, development and principles] Ankara Üniversitesi Ĕ̈itim Bilimleri Fakültesi Özel Ĕ̈itim Dergisi, 5(2), 1-13.

Kirk, S. A., Gallagher, J. J., \& Coleman, M. R. (2015). Educating exceptional children (14th ed.). Belmont, CA: Cengage.

Lindsay, G. (2003). Inclusive education: A critical perspective. British Journal of Special Education, 33(1), 3-12. doi: $10.1111 / 1467-8527.00275$

Miles, M. B., \& Huberman, A. M. (1994). Qualitative data analysis. Thousand Oaks, CA: Sage.

Milli Eğitim Bakanlı̆̆ı [Ministry of National Education] (2019a). Özel eğitim uygulama merkezi (okulu) I. ve II. kademe haftalık ders çizelgesi (orta veya ağır düzeyde zihinsel engelliler/otizmi olan çocuklar) [Special education application center (school) I. and II. level weekly timetable (children with moderate or severe intellectual disability/autism)]. https://orgm.meb.gov.tr/www/ilkogretim-haftalik-derscizelgeleri/icerik/669 adresinden edinilmiştir.

Milli Eğitim Bakanlığı [Ministry of National Education] (2019b). Özel eğitim iş uygulama merkezi (okulu) III. kademe haftalık ders çizelgesi (orta veya ağır düzeyde zihinsel engelliler/otizmi olan çocuklar) [Special education job application center (school) III. level weekly timetable (children with moderate or severe intellectual disability/autism)]. https://orgm.meb.gov.tr/meb_iys_dosyalar/2018_05/14154452_egitim_uygulama_III_kademe_hdc.pdf adresinden edinilmiştir. 
Özel Eğitim Hizmetleri Yönetmeliği [Special Education Services Regulation]. (2018). T.C. Resmi Gazete, (30471), 7 Temmuz 2018.

Özyürek, M. (2006). Engellilere yönelik tutumların değisştirilmesi [Changing attitudes towards disabled]. Ankara: Kök Yayıncılık.

Patton, M. Q. (2002). Qualitative research \& evaluation methods (3rd ed.). London: Sage Publications, Inc.

Saban, A. (2004). Giriş düzeyindeki sınıf öğretmeni adaylarının "öğretmen" kavramına ilişkin ileri sürdükleri metaforlar [Entry level prospectıve classroom teachers' metaphors about the concept of "teacher"]. Türk Eğitim Bilimleri Dergisi, 2(2), 131-155.

Saban, A. (2008). Okula ilişkin metaforlar [Metaphors about school]. Kuram ve Uygulamada Eğitim Yönetimi, 55(55), 459-496.

Saban, A. (2009). Öğretmen adaylarının öğrenci kavramına ilişkin sahip oldukları zihinsel imgeler [Prospective teachers' mental images about the concept of student]. Türk Eğitim Bilimleri Dergisi, 7(2), 281-326.

Sezer, E. (2003). Dilde ve edebiyatta yol metaforu [Road metaphor in language and literature]. Kitapllk Dergisi, $65,88-92$.

Shippen, M. E., Crites, S. A., Houchins, D. E., Ramsey, M. L., \& Simon, M. (2005). Preservice teachers' perceptions of including students with disabilities. Teacher Education and Special Education, 28(2), 9299. doi: $10.1177 / 088840640502800202$

Streubert, H. J., \& Carpenter, D. R. (2011). Qualitative research in nursing (5th ed.). Philadelphia: Lippincott Williams \& Wilkins.

Sendurur, Y., \& Barış, D. A. (2002). Müzik eğitimi ve çocuklarda bilișsel başarı [Music education and cognitive achievement of children]. Gazi Üniversitesi Gazi Eğitim Fakültesi Dergisi, 22(1), 165-174.

Şahin, F., \& Güldenoğlu, B. (2013). Engelliler konusunda verilen eğitim programının engellilere yönelik tutumlar üzerindeki etkisi [Investigation the effects of a special education training program on attitudes toward people with disabilities]. Amasya Üniversitesi Eğitim Fakültesi Dergisi, 2(1), 214-239.

Taşmektepligil, Y., Yılmaz, Ç., İmamoğlu, O., \& Kılcıgil, E. (2006). İlköğretim okullarında beden eğitimi ders hedeflerinin gerçekleşme düzeyi [Realizatıon level of physical education lesson's purposes in primary education schools]. Spormetre Beden Eğitimi ve Spor Bilimleri Dergisi, 4(4), 139-147. doi:10.1501/Sporm_0000000070

Tortop, H. S., Kandemir, B., Kaya, Ö. E., \& Demir, F. (2015). Öğretmen adaylarının zihin engelli birey kavramına yönelik algıları [Prospective teachers' perceptions on the concept of mentally disabled individual]. Abant İzzet Baysal Üniversitesi Eğitim Fakültesi Dergisi, 15(Özel Sayı), 307-322.

Vural, M., Esentaş, M., \& Işıkgöz, E. (2018). Engellilerde Egzersiz ve Spor Eğitimi Bölümü öğrencilerinin engellilere yönelik tutumlarının incelenmesi (İnönü Üniversitesi Örneği) [Investigation the attitudes to the disabled persons of the students of department of the exercise and sports education for disabilities]. CBÜ Beden Eğitimi ve Spor Bilimleri Dergisi, 13(1), 1-11. doi: 10.7827/TurkishStudies.10045

Yaralı, D. (2015). Öğretmen adaylarının özel gereksinimli bireylere yönelik tutumlarının bazı değişkenler açısından incelenmesi [Examining prospective teachers' attitudes towards special education lesson in terms of some variables]. Journal of Education Faculty, 17(2), 431-455. doi:10.17556/jef.02712

Yıldırım, A., \& Şimşek, H. (2011). Sosyal bilimlerde nitel araştırma yöntemleri [Qualitative research methods in the social sciences] (8. baskı). Ankara: Seçkin Yayıncılık. 
Yükseköğretim Kurulu [Council of Higher Education] (2019a). Resim-iş öğretmenliği lisans programı [Bachelor of arts teacher education]. https://www.yok.gov.tr/Documents/Kurumsal/egitim_ogretim_dairesi/YeniOgretmen-Yetistirme-Lisans-Programlari/Resim_Is_Ogretmenligi_Lisans_Programi09042019.pdf adresinden edinilmiştir.

Yükseköğretim Kurulu [Council of Higher Education] (2019b). Müzik öğretmenliği lisans programı [Bachelor of music teacher education]. https://www.yok.gov.tr/Documents/Kurumsal/egitim_ogretim_dairesi/YeniOgretmen-Yetistirme-Lisans-Programlari/Muzik_Ogretmenligi_Lisans_Programi.pdf _ adresinden edinilmiştir.

Ysseldyke, J. E., Algozzine, B., \& Thurlow, M. L. (2000). Critical issues in special education. Education, 17(4), 434-456. 


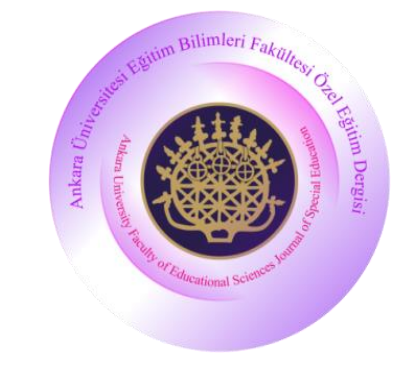

RESEARCH

\section{Ankara University Faculty of Educational Sciences Journal of Special Education}

Year: 2020, Volume: 21, No:1, Page No: 95-122

doi: 10.21565/ozelegitimdergisi.616520

Received Date: 03.09.19

Accepted Date: 03.01.20

OnlineFirst: 11.01 .20

\title{
Metaphorical Perceptions of Preservice Teachers of Fine Arts Education towards Students with Special Needs (The case of Gazi University)*
}

\author{
Eylem Dayı \\ Gazi University
}

\author{
Gökhan Açıkgöz ${ }^{* * *}$ \\ Gazi University
}

\author{
Ayşe Nur Elçi ${ }^{* * * *}$ \\ Gazi University
}

\begin{abstract}
This study aims to identify the metaphors belonging to the preservice teachers of the Fine Arts Education Department of Gazi Faculty of Education about the students with special needs. Phenomenology design was used within the scope of the qualitative research model. The study group consisted of 267 volunteer preservice teachers studying at the first, second, third and fourth grades of the Fine Arts Education Department. The data of the study were collected through a form with the open-ended statement of "To me, students with disabilities are like ......; because, ........ The content analysis technique was used for data analysis. The findings of the study show that preservice teachers produced 102 metaphors that were classified into eight categories. As a result, it is observed that the metaphors of flowers and everybody were used frequently about the students with special needs. It is concluded that preservice teachers' perceptions of students with special needs are generally positive.
\end{abstract}

Keywords: Students with special needs, metaphors, metaphorical perception, preservice teachers, fine arts education.

\section{Recommended Citation}

Dayı, E., Açıkgöz, G., \& Elçi, A. N. (2020). Metaphorical perceptions of preservice teachers of fine arts education towards students with special needs (The case of Gazi University). Ankara University Faculty of Educational Sciences Journal of Special Education, 21(1), 95-122. doi: 10.21565/ozelegitimdergisi.616520

\footnotetext{
${ }^{*}$ This study was presented as an oral presentation at the 28th National Special Education Congress, 11-13 ${ }^{\text {th }}$ October 2018, Eskişehir.

${ }^{* *}$ Corresponding Author: Assist. Prof., E-mail: eylemd@ gazi.edu.tr, https://orcid.org/0000-0003-1020-5846

${ }^{* * *}$ Res. Assist., E-mail: gokhan264@ gmail.com, https://orcid.org/0000-0002-8548-4360

****Res. Assist., E-mail: aysenurkucukelci@gmail.com, https://orcid.org/0000-0002-8153-4105
} 
All children differ from one another in terms of physical and learning characteristics. Most children benefit from the general education program. However, in order to fully benefit from education, the physical and /or learning characteristics of children with special needs differ from the norm above or below in that they require an individualized special education program and related services. The term "children with special needs" includes children with learning difficulties as well as children with a very high level of performance that need help to fulfill their potential and that require adaptation in the curriculum and instruction (Heward, Alber-Morgan, \& Konrad, 2017).

Public institutions of the Ministry of National Education General Directorate of Special Education and Guidance Services and private institutions of the General Directorate of Private Education are responsible for the education of children with special needs in Turkey. Institutions of the Ministry of National Education General Directorate of Special Education and Guidance Services provides courses to improve developmental areas and academic skills of children with special needs within the framework of individualized education programs (IEP). It needs to be pointed out that, in special education schools for children with moderate or severe intellectual disabilities/autism, "Visual arts and Handcrafts" and "Music and play" courses are provided three hours a week that is same for the courses of "Mathematics", "Life skills" and "Social skills" (Ministry of National Education, MoNE, 2019a, 2019b). In addition, the Special Education Services Regulation (2018) which regulates the education services of individuals in need of special education, informs that the courses in special education schools and classes are instructed by special education teachers. It also states that "religion course in primary schools; religion, visual arts, music and physical education courses and vocational courses are taught by the specialized teachers in secondary and high schools". When undergraduate programs are examined, it is seen that the "Special Education and Inclusion" course is offered two hours a week in the fourth year of the Art and Music Teacher Education Program of the Department of Fine Arts Education (Council of Higher Education, 2019).

Although all children are different in terms of their individual characteristics, children with special needs should have an individualized education program in order to fully benefit from the school. Although children in need of special education show more similarities than differences from those with normal development, a child with special needs differs significantly from normally developing peers. The way these differences are perceived and the type of education provided have a significant effect on the success of children in and after school (Heward et al., 2017; Özyürek, 2006).

Research is available about how individuals with special needs are perceived by prospective teachers. Tortop, Kandemir, Kaya, and Demir (2015) stated that preservice teachers' perceptions about the term "mentally disabled individual" including their responses to the question of how they perceive the definition of mental disability. Five themes out of 11 emerged, involving "individual who needs others to survive", "individual whose mental development is regressive", "individual whose social life is hindered", "individual who cannot fulfill some skills", and "individual in need of attention".

In their study, Shippen, Crites, Houchins, Ramsey, and Simon (2005) compared preservice teachers' perceptions of providing assistance to the students with special needs on two different scales (eg. refusal/acceptance and anxiety/calmness) before and after the completion of an entry course to special education. The results of the study showed that the special education course significantly reduced the preservice teachers' anxiety and refusal about assisting the students with special needs in general education settings.

Impecoven-Lind (2004) aimed to investigate prospective teachers' perceptions of students with special needs and provide the educators with information that could be used to better prepare future teachers for working with a different group of students and to modify the teacher training programs where necessary. The results showed that preservice teachers' perceptions of students with special needs were very positive. There were differences between the groups according to the early childhood, primary, secondary learning experiences of the teacher candidates. Several themes emerged as factors that shape preservice teachers' current perceptions of students with 
special needs. Among the most common factors were family, friends, work, school, practice-oriented experiences and religious beliefs.

It is important to determine the perceptions of the preservice teachers of the Fine Arts Education Department who attend the courses that have the same amount of hours as the basic compulsory courses they attend during undergraduate education. The opinions of prospective teachers towards the students with special needs that are thought to be in significant numbers in all levels of education can affect the approach of the teachers to their students and the educational services (Heward et al., 2017). If students with special needs are expected to be successful in educational environments, it is imperative to better understand the preservice teachers' perceptions. In addition, educators will be able to develop teacher education programs that better address the prejudices and misperceptions of the preservice teachers about students with special needs, when they better understand the perceptions that teacher trainees bring to the teacher education program (Impecoven-Lind, 2004).

Metaphors are one of the methods used to express feelings and opinions. The metaphor can be defined as "transferring the equivalence of something" or "reformulating" when defining the complex terms (Döş, 2010). It is the use of analogy and different ways of expressions to explain instead of using the known and accepted meaning of a word. Metaphors that communicate feelings and opinions in daily life and affect context-dependent perspectives can be used to clearly express the content of daily life and situations that are difficult to articulate or to convey to other party (or parties). Metaphors can be employed in various areas of education. For example, they are used in curriculum development and planning, educational management and sometimes for encouraging to learn and for developing creative thinking (Arslan \& Bayrakçı, 2006). The literature shows that many studies have focused on preservice teachers' perceptions and attitudes towards disabled people. However, no study has been found that directly investigates the perceptions of prospective teachers of the Fine Arts Education Department towards students with special needs. This study aims to identify the metaphors belonging to the preservice teachers of the Fine Arts Education Department of Gazi Faculty of Education about the students with disabilities. In this context, the answers for the following questions were sought:

1. What are the metaphors belonging to the preservice teachers of the Fine Arts Education Department of Gazi Faculty of Education for the students with special needs?

2. What are the conceptual categories and expressions of the metaphors emerged?

\section{Method}

\section{Research Model}

The study utilized phenomenology design within the scope of the qualitative research model. Studies using this design attempt to interpret the structure of the cases from the point of view of the people or groups who experience or can reflect the focus of the research (Büyüköztürk, Çakmak, Akgün, Karadeniz, \& Demirel, 2016; Creswell, 2007; Gedik, 2016).

\section{Study Group}

The participants were selected based on the purposive sampling method. Accordingly, the research was conducted with 284 volunteer preservice teachers enrolled in the first, second, third and fourth year undergraduate program of the Fine Arts Education Department of Gazi Faculty of Education in the spring semester of the 20172018 academic year. The responses of 17 participants were not taken into consideration because either the expressions on the form were left blank, incomplete or meaning integrity was lacking.

A total of $72.7 \%$ of the preservice teachers that participated in the research were female and the remaining participants were male. 17.6\% of the participants studying in the Fine Arts Education Department were in the first, $20.2 \%$ were in the second, $42.3 \%$ were in the third and $19.9 \%$ were in the fourth grade. 


\section{Data Collection}

In the study, the metaphors of preservice teachers about students with disabilities were gathered by using an open-ended questionnaire. The questionnaire consists of two parts. In the first part, there are questions about the participant's department, grade and in the second part, there are open-ended metaphorical statements that aim to uncover the perceptions of the prospective teachers about the students with disabilities.

\section{Data Analysis}

The content analysis technique was used in the analysis and evaluation of the metaphors written by the preservice teachers. In this study, the content analysis stages of metaphors were performed by using those in the similar studies (Anılan, 2017; Ateş \& Karatepe, 2013; Büyükalan Filiz \& Türkmenli, 2019; Derman, 2014; Ekici, 2016; Saban, 2004; 2008; 2009). The stages followed were screening and enumeration, coding, creation of categories, validity and reliability, and interpretation of the data.

Screening and enumeration of data. At this stage, first, the appropriateness of the forms filled out by the participants was examined. Seventeen out of 284 forms were not filled in line with the research purposes. Thus, these papers were excluded from the evaluation. Subsequently, the remaining forms were enumerated from one to 267.

Coding of data. At the coding stage, the metaphors were coded starting with number one. As a result of this process, 102 codes were identified. The codes and metaphors belonging to the preservice teachers were listed together and tabulated and frequency values were written.

Creation of categories. The statements of preservice teachers were examined in terms of their common characteristics and evaluated according to the characteristics and perspectives they emphasized about students with disabilities. As a result of this evaluation, eight categories were identified to represent the metaphors created.

Ensuring validity and reliability. In this study, to ensure validity, attention was given to distribute the forms to volunteer preservice teachers, to allow enough time to fill out the forms and to prevent the exchange of help among participants while working on their forms. The data analysis process was reported in each stage and in detail.

In order to ensure the reliability of the study, to verify whether the relevant conceptual categories of the codes (metaphors) represent the perceptions of preservice teachers towards students with disabilities, the codes created by the three researchers were compared (Creswell, 2007; Houser, 2015; Streubert \& Carpenter, 2011). After three researchers coded the research data separately, the list of codes and categories was finalized. The reliability of the data analysis was calculated by using the formula "Reliability $=$ consensus / consensus + disagreement" (Miles \& Huberman, 1994). As a result of the calculation, the mean reliability between encoders was found .93. In addition, by assigning numbers to the participants (such as OA2), the opinions of the preservice teachers were explained in the findings. A word cloud was prepared for data evaluation. The program available at "https://wordart.com/create" was used in the preparation of the word cloud.

Interpretation of data. The metaphors gathered during the data analysis along with the expressions have been categorized and presented in tables and figures.

\section{Results, Discussion and Conclusion}

This study aimed to examine the metaphors belonging to preservice teachers of the Fine Arts Education Department of Gazi Faculty of Education about the students with special needs. According to the data, 267 preservice teachers of the Department of Fine Arts Education were found to produce 102 metaphors in 8 categories: "Mysterious and awaiting to be discovered", "Fragile and Delicate", "Beauties of Life", "Like Everyone/Normal", "In need of attention and help", "Difference", "Purity" and "Endurance". When the metaphors produced by prospective teachers are examined, it is seen that a significant number of students perceive students with special 
needs as "flowers, everyone, puzzle, undiscovered land, angel and baby". These metaphors express how teacher candidates perceive students with special needs, their experiences and beliefs or attitudes towards students with special needs (Aubusson, 2002; Ekici, 2016). Especially the "beauties of life" category is seen to have the highest number of metaphors ( 24 metaphors). It can be said that most of the metaphors produced in these categories are positive, and preservice teachers associate students with special needs with positive and optimistic emotions that help them see the beautiful side of life. There is no similar research available in the previous literature. However, the results of the studies conducted on how the preservice teachers from different programs perceive the students with special needs were found to be positive (Akyıldız, 2017; Impecoven-Lind, 2004; Vural, Esentaş, \& Işıkgöz, 2018; Yaral1, 2015)

Nearly half of the metaphors $(N=61)$ belonging to the preservice teachers were written once. This data shows the importance of individual experiences in the formation of different metaphors (Cisek, 1999). Therefore, it is believed that the individual experiences and creativity of the particiapants are highly rich. Impecoven-Lind (2004) stated that there were differences between the groups according to the program experiences of preservice teachers (early childhood, primary, secondary). In addition, learning and practice were stated to be among the most common factors shaping the current perceptions of prospective teachers towards students with special needs. Therefore, in addition to the two-hour "Special Education and Inclusion" undergraduate course, minimum of two other courses about topics such as "Behavior Management and Adaptation" can be recommended to maintain positive attitudes. In addition to the positive perception of the differences in children with special needs, the training about these differences has a significant impact on the success of children in and after school (Heward et al., 2017).

Although characteristics of the metaphors "Purity" and "Mysterious and awaiting to be discovered" belonging to the preservice teachers show similarities, they were considered in two different categories. In the "Purity" category, prospective teachers mostly used metaphors and expressions stating that they also have certain levels of potential. In the "Mysterious and awaiting to be discovered" category, the metaphors show that students with special needs can have different characteristics beyond their disability. As a result, preservice teachers have positive thoughts about revealing and developing the potential of students with special needs in both categories. However, it is seen that they do not express how to reveal these potentials. The data signal that it is necessary to train teacher candidates of the Fine Arts Department about how to conduct art and music lessons with students with special needs and how to reveal the potential that is thought to exist. Prospective teachers will need this training especially when they work at special education schools or work with children in need of special education. For example, Çetin (2004) aimed to identify the difficulties experienced by a teacher working in the field of special education. In this study, the teachers who graduated from different departments working in various training and special education and rehabilitation centers stated that they have difficulties in managing problem behaviors, evaluating students with special needs, and using different teaching methods effectively since they did not receive sufficient training in their preservice programs. Another finding of this study was the need for in-service training and resources and materials for the special education field. Shippen et al (2005) showed that preservice teachers significantly reduced the level of anxiety and disagreement/refusal about assisting students with special needs in general education settings after the completion of the introductory course for special education. Therefore, it is suggested that this positive situation should be supported by additional courses and practice during preservice training. The positive perception alone does not always suffice to achieve the goals.

Preservice teachers produced 18 metaphors in the "Differences" category and 8 metaphors in the "Normal/like everybody" category which seems to be the opposing category. When the metaphors in the "Differences" category are examined, it is seen that differences such as "important talent, fingerprints, red apples among green apples" are emphasized in terms of their special abilities as well as the barriers of these students. Prospective teachers' perception of differences is believed to positively affect their behaviors towards their prospective students during their teaching profession. When the metaphors such as "privileged, colors, special" in the "Differences" category and their reasons are examined, it is observed that providing education about the 
differences of students with special needs is considered essential. Although children with special needs have more similarities than differences in comparison to children with normal development, a child in need of special education differs significantly from normal peers of the same age (Heward et al., 2017). The rationale used by prospective teachers to explain metaphors in this category gives the impression that students with special needs are aware of their different educational needs. When the metaphors in the "normal / like everyone" category and their reasons were examined, it is seen that students with special needs are first and foremost considered as a human being and citizen, a member of society. These statements are in line with the normalization principle that is effective for special education services in the world and in Turkey. The principle of normalization aims to ensure that individuals with special needs benefit equally from the rights and opportunities that other members of society enjoy (Akçamete, 2009, Kargın, 2004; Lindsay, 2003; Ysseldyke, Algozzine, \& Thurlow, 2000). Based on this principle, "integration and inclusion" practices are carried out throughout the world. Although this study does not include enrolment in a special education course as a variable, there are some participants who were enrolled in the "Special Education and Inclusion" course. The rationale used by prospective teachers in explaining the metaphors in this category can be the result of the "Special Education and Inclusion" course. Similarly, Şahin and Güldenoğlu (2013) stated that the undergraduate education program including the course entitled "Special Education and Inclusion" had positive effects on the attitudes of university students towards disabled people.

The "Fragile and delicate" category, with six metaphors and the "Endurance" category, which produced 11 metaphors, were seemingly contrasting. The "fragile and delicate" category includes objects (flowers, crystals, butterflies, etc.) that we should act with precision not to harm in life. This point of view gives the impression that teacher candidates think that students with special needs may be more psychologically sensitive due to their special needs. However, it reveals that this should not be a situation specific to the disability and should be considered as a human characteristic. A child's world of emotion is not only a natural indicator of its basic characteristics but also a social composition resulting from experience and learning. In other words, if a child cannot understand and interpret the behaviors and communication of others, this may have long-term social consequences on the child's emotional development. This situation can be changed socially (Kirk, Gallagher, \& Coleman, 2015). On the other hand, the metaphors in the "Endurance" category illustrate that the terms used to define the concept of strength (struggle, indestructible rock, etc.) and resources (mountain, tree, roots of a tree, etc.) are referred. Preservice teachers' opinions that they can stay strong against life and the difficulties they face despite the special needs of the students can be understood from the rationalized expressions of their metaphors. The metaphors and expressions produced by these participants in the endurance category are particularly significant for this research.

When the category "in need of attention and help" is examined, it is seen that prospective teachers developed 18 metaphors. The rationale for these metaphors shows resemblance to those mentioned in the study by Tortop et al. (2015) who revealed them themes in the following: "Individuals whose social life has been hindered", "individuals who cannot fulfill the skills" and "individuals who need attention". In this category, teacher candidates explain the attention and the need of help of students with special needs with various metaphors and rationale. For example, the expressions like "baby, needy, cat, butterfly, dehydrated tree, God's blessing" signal the state of being always in need; "bird in the cage, new seed, baby's call for mom" show the continuity of need in terms of assistance provided to them. This category signifies that preservice teachers who think that there should be continuous attention and help so that they have insufficient knowledge and experience about students with special needs. These preservice teachers who have the idea that the need for professional education in terms of the provision of services can eliminate the obstacles in their teaching profession. This is because while deficiency is personal, disability may vary depending on the environment and the services provided (Heward et al., 2017). The metaphor of "God's blessing" suggests that religious beliefs affect the preservice teachers' perceptions. Similarly, Impecoven-Lind (2004) stated that religious beliefs are among the most common factors that shape the preservice teachers' perceptions of students with special needs.

As a result, the data confirm that the metaphors formed by the preservice teachers are positive. Although this is very important for a prospective teacher, there is still a need to establish appropriate educational 
environments in addition to the need of maintaining the positive attitude and perception to help achieve success for the students with special needs. Therefore, it is recommended that teacher candidates should be supported with practice-oriented courses as well as theoretical ones to work with students with special needs effectively during their undergraduate studies. In further research, action research with teacher candidates of the Department of Fine Arts Education can concentrate on designing and instructing courses for a group of students with special needs. At the end of the research, preservice teachers can reflect on their experiences. Taking these variables into consideration, other studies can be conducted comparing the metaphorical perceptions of prospective teachers towards students with special needs. Finally, the metaphorical perceptions of the preservice teachers of the Department of Special Education and those of the Department of Fine Arts can be compared. 